\title{
Contrasting mechanisms of magma fragmentation during coeval magmatic and hydromagmatic activity: the Hverfjall Fires fissure eruption, Iceland
}

\author{
E. J. Liu ${ }^{1}$ - K. V. Cashman ${ }^{2}$ - A. C. Rust ${ }^{2}$ - A. Höskuldsson ${ }^{3}$
}

Received: 12 January 2017 / Accepted: 7 August 2017 /Published online: 7 September 2017

(C) The Author(s) 2017. This article is an open access publication

\begin{abstract}
Growing evidence for significant magmatic vesiculation prior to magma-water interaction (MWI) has brought into question the use of 'diagnostic' features, such as low vesicularities and blocky morphologies, to identify hydromagmatic pyroclasts. We address this question by quantifying co-variations in particle size, shape and texture in both magmatic and hydromagmatic deposits from the Hverfjall Fires fissure eruption, Iceland. Overlapping vesicularity and bubble number density distributions measured in rapidly quenched magmatic and hydromagmatic pyroclasts indicate a shared initial history of bubble nucleation and growth, with substantial vesiculation prior to MWI. Hydromagmatic fragmentation occurred principally by brittle mechanisms, where the length scale and geometry of fracturing was controlled by the bubble population. This suggests that the elevated fragmentation efficiency of hydromagmatic deposits is driven, at least in part, by brittle disintegration of vesicular pyroclasts due to high thermal stress generated during rapid cooling. In this way, the shape and size distributions of hydromagmatic pyroclasts, both critical input parameters for ash dispersion models, are strongly influenced by the dynamics of
\end{abstract}

Editorial responsibility: J.D.L. White

Electronic supplementary material The online version of this article (doi:10.1007/s00445-017-1150-8) contains supplementary material, which is available to authorized users.

\section{E. J. Liu}

ej154@cam.ac.uk

1 Department of Earth Sciences, University of Cambridge, Downing Street, Cambridge CB2 3EQ, UK

2 School of Earth Sciences, University of Bristol, Wills Memorial Building, Bristol BS8 1RJ, UK

3 Institute of Earth Sciences, University of Iceland, Reykjavík, Iceland vesiculation prior to MWI. This result underlines the need to analyse multiple grain-size fractions to characterise the balance between magmatic and hydromagmatic processes. During the Hverfjall Fires eruption, the external water supply was sufficient to maintain MWI throughout the eruption, with no evidence for progressive exhaustion of a water reservoir. We suggest that both the longevity and the spatial distribution of MWI were determined by the pre-existing regional hydrology and represent continuous interaction between a propagating dike and a strong groundwater flow system hosted within permeable basalt lavas.

Keywords Magma fragmentation · Hverfjall Fires · Phreatomagmatism

\section{Introduction}

Hydromagmatic activity is characterised by much greater fragmentation efficiencies (i.e. producing more fine-grained ash), and therefore more widespread tephra deposition, than equivalent magmatic eruptions (e.g. Walker and Croasdale 1971; Walker 1973; Houghton and Nairn 1991; Houghton et al. 1999; Mastin et al. 2004; Németh and Cronin 2011; Németh et al. 2012; Van Otterloo et al. 2013; Gjerløw et al. 2015; Liu et al. 2015b). Anticipating the unique hazards of eruptions involving explosive magma-water interaction (MWI; Cioni et al. 1992; Mastin et al. 2004; Zimanowski et al. 2003; Németh and Cronin 2011; Dellino et al. 2012; Liu et al. 2015b) requires that 'wet' vs. 'dry' eruptions can be determined from the deposit characteristics of past eruptions. Wet vs. dry deposits are typically distinguished on the basis of both sedimentological characteristics (e.g. Lorenz 1974; Chough and Sohn 1990; Cole et al. 2001; Solgevik et al. 2007) and the nature of the constituent ash particles. 
Of the latter, small grain sizes and ash with blocky morphologies and low vesicularities are often taken as diagnostic of hydromagmatic eruptions (e.g. Heiken and Wohletz 1985; Büttner et al. 1999; Büttner et al. 2002). Increasing evidence suggests, however, that the boundary between magmatic and hydromagmatic deposits may be blurred, and that magmatic and hydromagmatic fragmentation styles often occur simultaneously (Cioni et al. 1992; Grættinger et al. 2013; Murtagh and White 2013; Liu et al. 2015a; White and Valentine 2016). A more complete understanding of the controls on hydromagmatic fragmentation requires comparison of the products of hydromagmatic and magmatic eruptions to identify not only their differences but also their shared characteristics.

Contrasting fragmentation efficiencies between wet and dry eruptions are highlighted by compilations of grain size data for mafic deposits (e.g. Walker and Croasdale 1971; Walker 1971; Houghton and Hackett 1984; Cole et al. 2001; Liu et al. 2015a). In contrast to those mafic eruptions in which coarse inertial fragmentation is driven by rapid vesiculation (Mangan and Cashman 1996; Parfitt 1998; Mangan et al. 2014), extensive melt fragmentation during MWI reflects brittle breakage in response to high rates of thermal to mechanical energy transfer (Peckover et al. 1973; Colgate and Sigurgeirsson 1973; Sheridan and Wohletz 1983; Kokelaar 1986; Wohletz 1986; Zimanowski et al. 1991; Zimanowski et al. 1997; Büttner et al. 2002; Van Otterloo et al. 2015). Here, brittle fragmentation is driven by rapid vaporisation and expansion of external water ('steam explosivity'), and/or thermal stress created by rapid cooling and contraction of pyroclasts.

The physical state of magma at the point of fragmentation can be inferred from primary vesicle (and crystal) textures (e.g. Klug and Cashman 1994; Cashman and Blundy 2000; Cashman 2004; Lautze and Houghton 2007; Wright et al. 2012; Rust and Cashman 2011; Stovall et al. 2011, 2012; Alfano et al. 2011; Murtagh and White 2013; Cioni et al. 2014). In the products of mafic magmatic eruptions, only rapidly cooled clasts, such as ash or the quenched outer rims of lapilli, closely approximate the primary bubble population at the time of fragmentation. The products of hydromagmatic eruptions should also quench rapidly and thus preserve fragmentation information. Vesicle measurements are comparatively scarce for mafic hydromagmatic deposits, however, and most of these data are for eruptions involving interaction with surface water. Overall, the products of these 'Surtseyan' eruptions span an exceptionally broad range of vesicularities, from 5 to $90 \%$ (Fig. 1). These data show that whilst low vesicularities may be a feature of deep-seated diatremes (e.g. Ross and White 2012), the vesicularity ranges of Surtseyan-style eruptions and Hawaiian lava fountains overlap between 40 and $70 \%$ (e.g. Stovall et al. 2011). In other words, moderate to high vesicularity is not sufficient to rule out a hydromagmatic origin. Furthermore, the range of bubble number densities (BNDs) is also comparable between magmatic and hydromagmatic mafic deposits and is independent of clast vesicularity; these similarities suggest that magma involved in both eruption styles shares a common ascent (decompression) path. Most importantly, the high BNDs and vesicularities of many hydromagmatic pyroclasts indicate substantial magmatic vesiculation prior to MWI (e.g. Mastin et al. 2004).

Explosive hydromagmatic activity includes intermittent steam-laden tephra jets and/or variably water-saturated base surges (e.g. Pórarinsson 1967; Moore 1967; Chough and Sohn 1990; Németh et al. 2006). Base surges are turbulent, low-particle concentration density currents that spread away from the base of a collapsing debris-laden eruption column (Moore 1967; Waters and Fisher 1971; Fisher 1979; Németh et al. 2006). Variations in hydromagmatic eruptive style are controlled by complex interactions between intrinsic (magmatic) and extrinsic (environmental) factors that determine the efficiency of thermal to mechanical energy transfer, including (a) the magma-water ratio, (b) the depth of MWI, (c) the properties of the host substrate and (d) the geometry of the conduit (Wohletz and Sheridan 1983; Wohletz 1983; ArandaGómez and Luhr 1996; Sohn 1996; Solgevik et al. 2007; Pedrazzi et al. 2013). The interplay between magmatic vesiculation and the dynamics of MWI has important implications for fragmentation mechanisms, but is not yet fully explored in existing models of hydromagmatism (Murtagh et al. 2011; Murtagh and White 2013; Liu et al. 2015b). To what extent do changes in the conditions of magma ascent (i.e. ascent rate, volatile content and degree of vesiculation) influence the nature of how magma and water interact?

In this study, we explore the effect of vesiculation prior to MWI on fragmentation by comparing coeval magmatic and hydromagmatic deposits from the 2500 BP Hverfjall Fires basaltic fissure eruption, Iceland. As all vents shared the same initial magma composition and feeder system, differences in pre-fragmentation magma texture are inferred to have been minimal and we interpret differences in the morphology and textures of pyroclasts as recording the effects of fragmentation under different near-surface conditions. The excellent preservation of these largely unaltered/nonpalagonitised deposits provides an opportunity to investigate not only the role of water on the efficiency and mechanism of magma fragmentation but also the conditions under which MWI took place, including the physical state of the magma. By exploring co-variation in pyroclast morphology, vesicle texture and density over the full range of available grain sizes and stratigraphic exposure, we identify the controls on the length scale and geometry of hydromagmatic fragmentation and, consequently, the physical mechanisms of fine ash generation. Furthermore, we consider the extent to which variations in pyroclast properties and deposit structure reflect changes in either the conditions of magma ascent or the environment of MWI. 

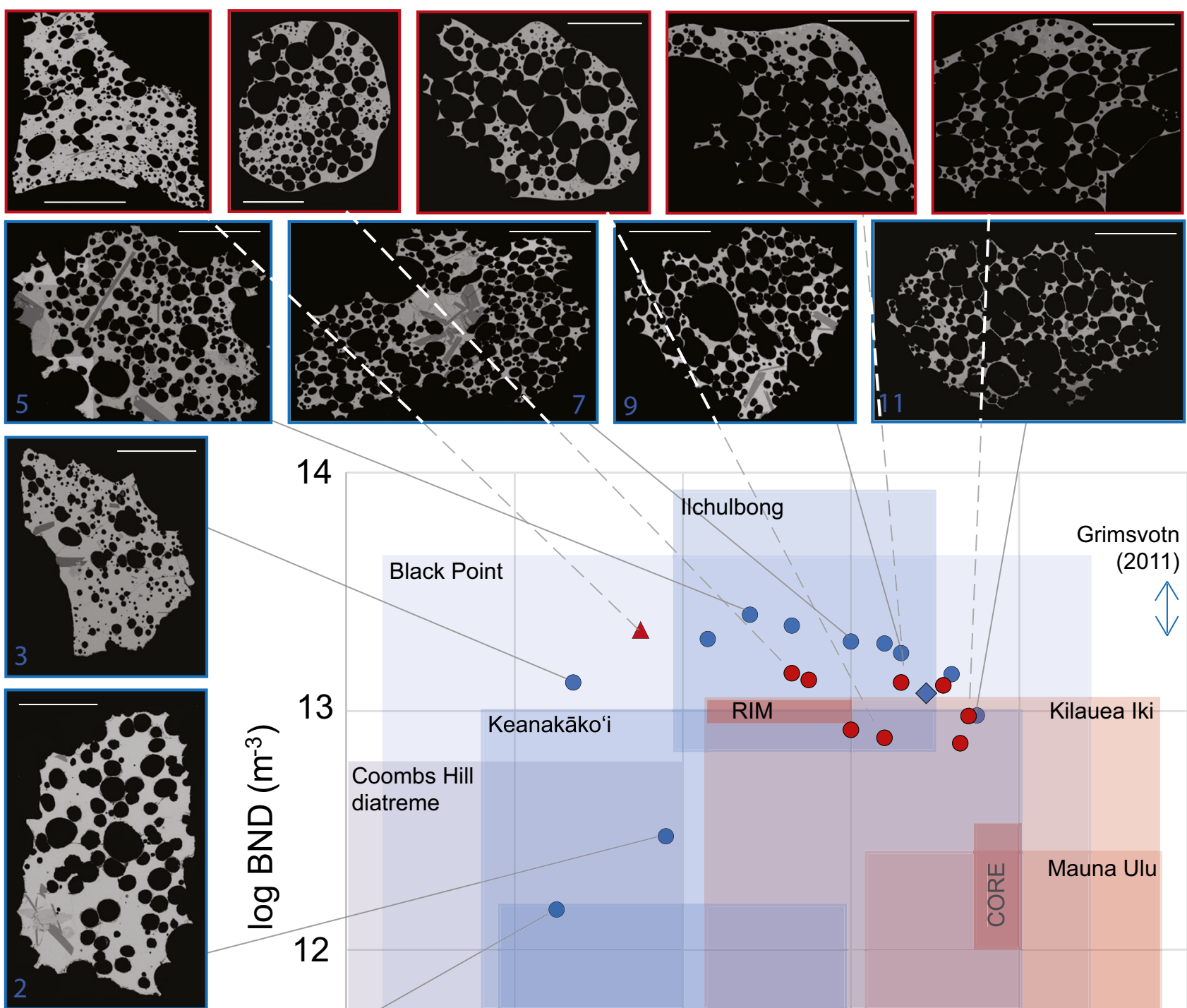

13

14

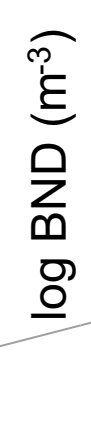

13
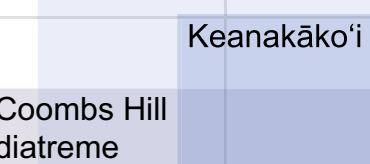

diatreme

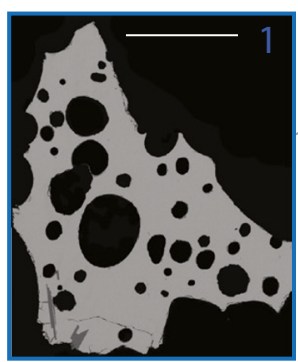

Fig. 1 Bubble number densities (log BND; $\mathrm{m}^{-3}$ ) and vesicularities (2D) for hydromagmatic (blue; sample site 2.3) and magmatic (red; sample site Q1) clasts from the Hverfjall Fires, measured from 1 to $2 \mathrm{~mm}$ (circles), 4 $8 \mathrm{~mm}$ (diamond) and 16-32 mm (triangle) particle sizes. A selection of datapoints are annotated with the corresponding backscattered electron SEM images for illustration. The white scale bars on all SEM images are $0.5 \mathrm{~mm}$. Shaded fields highlight the ranges of BNDs and vesicularities from other hydromagmatic (blue) and magmatic (red) basaltic eruptions: Black Point (US; Murtagh and White 2013), Ilchulbong tuff cone (Korea; Murtagh et al. 2011), Keanakako'i (Hawaii; Mastin et al. 2004), Capelas (Azores; Mattsson 2010); Kilauea Iki and Mauna Ulu eruptions of
Kilauea (Hawaii; Stovall et al. 2012; Porritt et al. 2012; Parcheta et al. 2013). For Kilauea Iki, cores and rims from single clasts are shown individually where analysed separately (Stovall et al. 2012). Vesicularity and BND ranges for the Coombs Hill diatreme are show by the grey shaded field (Ross and White 2012). The range of BNDs for the 2011 Grímsvötn deposits, for which vesicularity data are not available, are shown by the blue arrowed lines (Liu et al. 2015a). The range of vesicularities for the lava fountain deposits of the 2000 and 2006 Etna (Italy; Polacci et al. 2009) and Pu'u'O'o-Kupaianaha (Kilauea; Mangan et al. 1993) eruptions are shown by the red arrowed lines, for which $\mathrm{N}_{\mathrm{v}}$ data are not available 


\section{Geological setting}

The Krafla volcanic system (KVS; Fig. 2a) is located in Iceland's Northern Volcanic Zone and comprises a central caldera with a transecting fissure system distributed over an area of $900 \mathrm{~km}^{3}$ (Thordarson and Höskuldsson 2008). Rifting in the KVS is controlled by the regional stress field, with fractures and fissures striking $\mathrm{N}$ to NNE perpendicular to the extensional stress direction (Hjartardóttir et al. 2012).

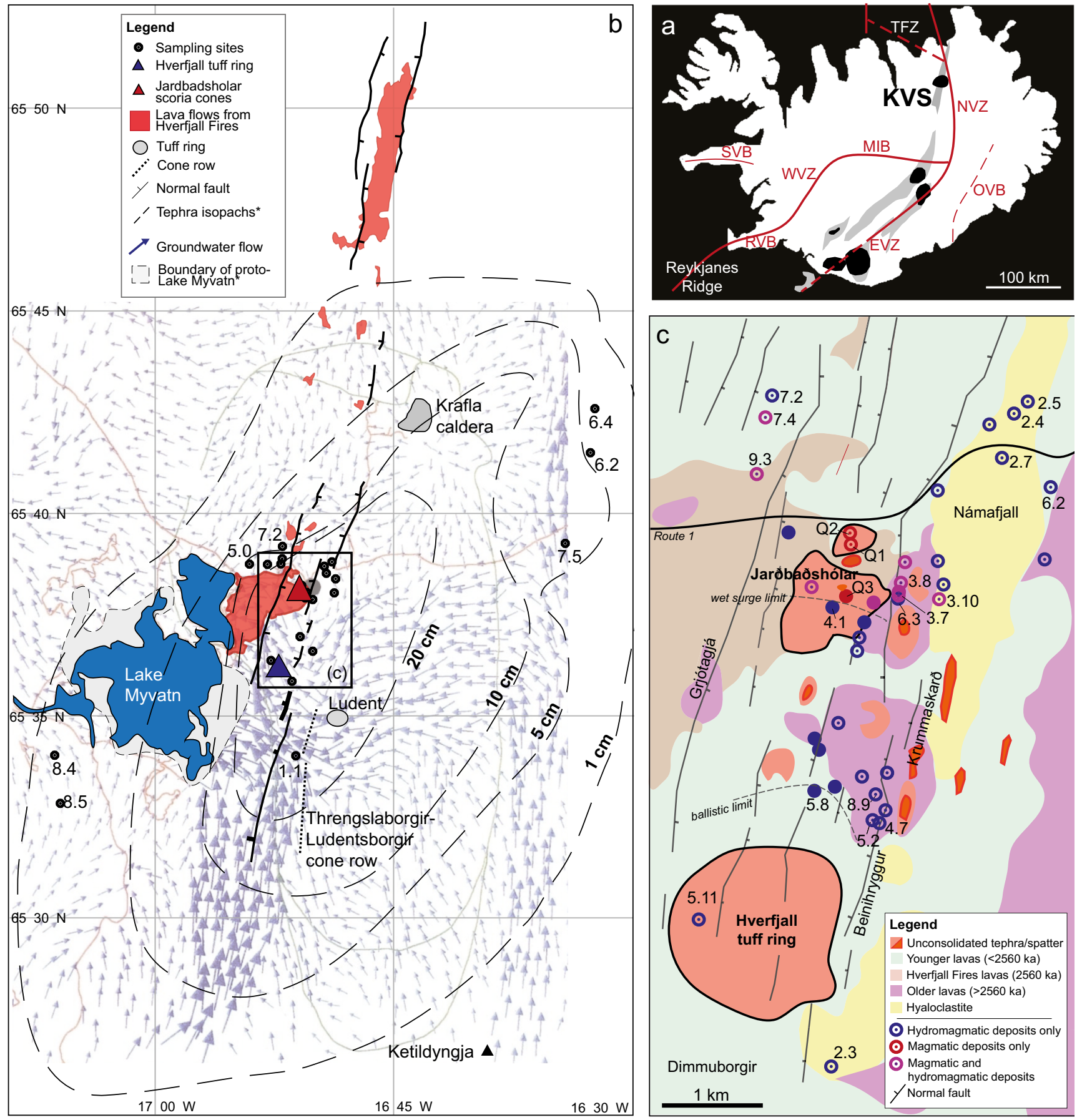

Fig. 2 Study area. a Location of the Krafla volcanic system (KVS) in the larger tectonic setting of Iceland. b Regional scale map of the KVS, showing sampling locations and corresponding labels (black symbols; Table S2, isopachs for the hydromagmatic fall deposit (*redrawn from Mattsson and Höskuldsson 2011), and the locations of lava flows erupted during the Hverfjall Fires (red shaded regions; from Sæmundsson 1991).
Groundwater flow vectors are depicted by the blue arrows (redrawn from Einarsson et al., 2004). The previous extent of the proto-Lake Mývatn is shown by the grey-dashed region. $\mathbf{c}$ Detailed map of area enclosed by black rectangle in Fig. 2, showing the locations of sampling sites that are discussed in the text superimposed onto GoogleEarth topographic imagery 
The Mývatn region lies within the KVS and comprises a shallow lake-filled depression, bounded to the west by low Plio-Pleistocene basalt ridges and to the east by the young Námafjall hyaloclastite ridge (Pórarinsson 1979). Postglacial volcanic activity in the region commenced 6000 years ago with the Ludent Fires, during which explosive activity formed the Ludent tuff ring. Subsequently, the Mývatn area was covered by the extensive Older Laxáhraun pahoehoe lava flow $(\sim 3.8 \mathrm{ka})$ that originated from a shield volcano $25 \mathrm{~km}$ SE of Mývatn. This lava flow dammed the western drainage outflow from the depression towards Laxádalur, forming protoLake Mývatn (Fig. 2b; Einarsson 1982).

Following a long period of volcanic quiescence in the Mývatn region, activation of a $\sim 50-\mathrm{km}$-long fissure segment within the Krafla volcanic zone initiated the Hverfjall Fires 2500 years ago (Pórarinsson 1952; Sæmundsson 1991; Mattsson and Höskuldsson 2011). Effusive activity occurred intermittently along the NNE-SSW aligned fissure, which extended both north and south of the central Krafla caldera (Fig. 2; Sæmundsson 1991). Most of the activity was concentrated at the southernmost tip of the fissure, in Mývatn, where explosive activity localised at two coeval fissure vents that formed a (magmatic) scoria cone within the composite Jarðbaðshólar cone complex (hereafter referred to singularly as Jarðbaðshólar for simplicity) and the (hydromagmatic) Hverfjall tuff ring (Mattsson and Höskuldsson 2011). To avoid confusion in terminology, all references made to the 'Hverfjall vent' refer to the hydromagmatic vent and associated deposits, whilst the full name of the Hverfjall Fires is used when referring to the eruptive episode in its entirety.

The Threngslaborgir-Ludentsborgir cone row, extending south from the Hverfjall tuff ring, formed during a subsequent fissure eruption dated to $\sim 2.1 \mathrm{ka}$. This eruption also fed the Younger Laxáhraun lava flows, which cover much of the area surrounding Lake Mývatn (Pórarinsson 1952). Interaction between the Younger Laxáhraun lavas and the proto-Lake Mývatn modified the shape of the lake basin to its present day form, extending it northwards to form the northern basin (Fig. 2b). Two major rifting episodes have taken place in the KVS in historical times: the 1724-1729 Mývatn Fires and the 1975-1984 Krafla Fires (Pórarinsson 1952; Sæmundsson 1991).

The spatial distribution of the Hverfjall Fires deposits along the entire length of the fissure was mapped in detail by Sæmundsson (1991), and the deposits in the Mývatn region later re-visited by Mattsson and Höskuldsson (2011). Most extensive are distal airfall tephra deposits from the initial eruptive phase of the Hverfjall hydromagmatic vent, which are found at distances of $\leq \sim 20 \mathrm{~km}$. Isopach contours for this deposit, which also include thickness measurements of subsequent base surge deposits from Hverfjall, are elongated to the NNE and SSW (Fig. 2b; Sæmundsson 1991; Mattsson and Höskuldsson 2011). Interbedded magmatic and hydromagmatic deposits indicate that the Hverfjall vent and at least one vent within the Jarðbaðshólar cone complex were active simultaneously. A previous study suggested that magmatic activity at Jarðbaðshólar began after the onset of hydromagmatic activity at Hverfjall, with the onset of activity at Jarðbaðshólar (closer to the inferred source in the Krafla central caldera) and the consequent reduction in magma supply rate to the Hverfjall vent, invoked to explain a temporal change in hydromagmatic eruptive style from fall-dominated to surge-dominated deposition (Mattsson and Hoskuldsson 2011).

Although generally referred to as a tuff ring, the Hverfjall edifice has morphological properties transitional between those typical of tuff cones and tuff rings (Fig. 3a; Wohletz and Sheridan 1983; Sohn 1996; White and Ross 2011; Table S1). The low slope angle (18 ${ }^{\circ}$ maximum; $15^{\circ}$ average) and the low height/crater rim ratio $(0.125)$ are well within the characteristic ranges of tuff rings (White and Ross 2011 and references therein). However, the total height of the edifice (125 m maximum) is substantially greater than typically observed in tuff rings $(<50 \mathrm{~m})$ and is instead more consistent with those of consolidated tuff cones (White and Ross 2011). Similarly, 'over-sized' tuff rings and cones have been observed in Hawaii (Honolulu formation) and the Galapagos, but always in coastal littoral settings where the intrusion of seawater into highly permeable basalt lavas provides a sustained source of water (Lorenz 2003). This association suggests that water supply is important and that regional hydrology has a strong control on the dynamics of MWI and the resulting landforms (e.g. Sohn 1996; Lorenz 2003).

Hydromagmatic activity at the Hverfjall vent has been attributed to interaction with surface water (Mattsson and Höskuldsson 2011). Yet the absence of lake sediments beneath even the most proximal hydromagmatic deposits (which also preserve terrestrial tree moulds; Einarsson, 1982; Pórarinsson 1952) raises the question of whether the spatial extent of proto-Lake Mývatn extended as far as the Hverfjall tuff ring. Furthermore, the lack of field evidence for a late-stage transition to 'dry' magmatic activity, as is commonly observed for other hydromagmatic eruptions (e.g. Capelas, Azores; Solgevik et al. 2007; El Caracol, Mexico; Kshirsagar et al. 2016; Surtsey, Iceland; Pórarinsson 1967; Hunga Ha'apai, Tonga, Vaughan and Webley 2010), suggests a near-continuous water supply sufficient to maintain MWI throughout the eruption. This continuity in hydromagmatic activity is inconsistent with a sub-lacustrine eruption. The present Lake Mývatn, which 

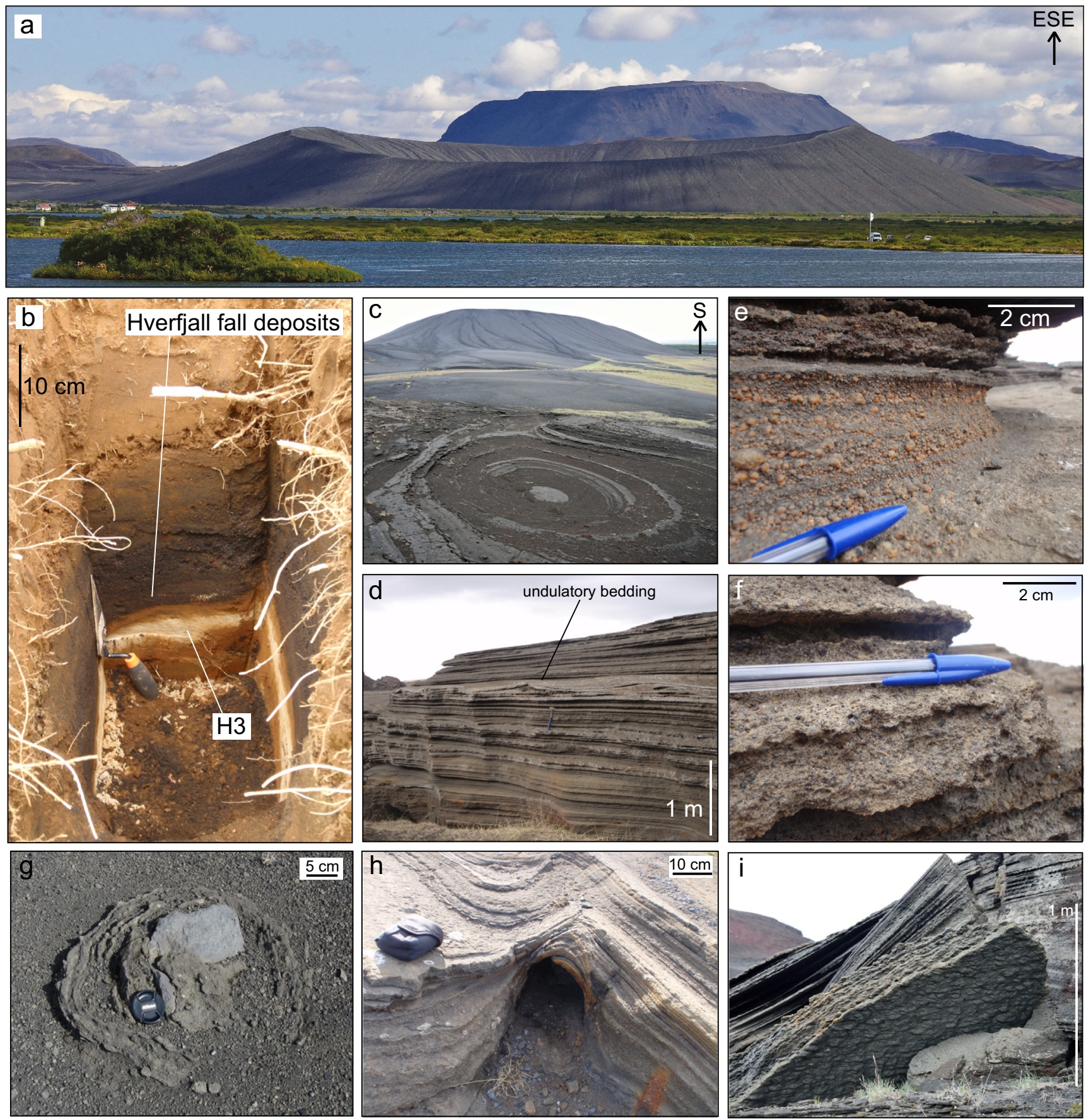

Fig. 3 Sedimentary features of the hydromagmatic deposits. a The Hverfjall tuff ring, viewed from the NW shore of Lake Mývatn. b Hverfjall deposits lie stratigraphically above the widespread Hekla-3 silicic ash layer, separated by $1-3 \mathrm{~cm}$ of soil [site 9.3]. $\mathrm{c}$ Weathering of base surge deposits has produced characteristic circular erosional features [site 8.9]. d Long wavelength undulatory bedding in surge deposits [site 8.9]. The wavelength of bedding undulations varies between 2.5 and $3.1 \mathrm{~m}$, with a wave height of $\sim 11 \mathrm{~cm}$. Similar base surge deposits at
Taal, Philippines, have a slightly longer wavelength of $5.5 \mathrm{~m}$ and a wave height of $70 \mathrm{~cm}$ at the same distance from the respective vent location (Waters and Fisher 1971). e Accretionary lapilli tuff in the upper surge units [site 8.9]. f Poorly sorted massive lapilli tuff in lower surge units [site 8.9]. g Impact structure showing surrounding soft sediment deformation. h Tree mould in lower surge unit [site 4.1]. i Flute marks on the underside of beds in the stratified lapillus tuff units [site 5.8]

groundwater at a rate of $\sim 30 \mathrm{~m}^{3} \mathrm{~s}^{-1}$ (Kristmannsdóttir and Ármannsson 2004). Below we suggest that the hydromagmatic activity at the Hverfjall vent was fuelled by an actively replenished groundwater source. 


\section{Methods}

\section{Samples}

Fieldwork was undertaken in 2013 and 2014. GPS coordinates and thickness data for all locations where observations were made and/or samples were collected and are listed in the supplementary materials (Fig. 2; Table S2, supplementary information). The deposits of the Hverfjall Fires are easily identifiable in the field as they are stratigraphically above the widespread silicic Hekla-3 (H3) marker bed (Fig. 3b; Sæmundsson 1991). Samples from six locations-four hydromagmatic and two magmatic-were selected for detailed morphological and textural analysis (Table 1). All hydromagmatic samples are from the unconsolidated basal fall unit collected at different distances from the Hverfjall vent: they represent the opening phase of hydromagmatic activity. Subsequent surge deposits are indurated and partially palagonised, precluding measurements of individual particle properties or deposit grain size distributions. Magmatic samples are from quarried exposures through the scoria cone edifice, and the surrounding tephra blanket up to a distance of $1.3 \mathrm{~km}$ from the vent. With the exception of one locality (Q3), all sampled deposits clearly overlie H3 ( \pm hydromagmatic units) and are therefore unequivocally linked to the Hverfjall Fires eruptive episode, rather than to earlier activity within the Jarðbaðshólar cone complex.

\section{Granulometry}

Grain size distributions (GSDs) were measured for all 23 hydromagmatic basal fall deposit sample locations (1.5 to $19 \mathrm{~km}$ from the Hverfjall vent) and six magmatic deposits (0.2 to $1.3 \mathrm{~km}$ from the Jarðbaðshólar vent active during the Fires). Ash samples were cleaned in an ultrasonic bath for 3$5 \mathrm{~min}$ and dried overnight at $80^{\circ} \mathrm{C}$. Dried samples were sieved manually in $1 / 2$ phi $(\varphi)$ intervals from $-3 \varphi$ to $>5 \varphi$ ( 8 to $<0.032 \mathrm{~mm} ; \varphi=-\log _{2} d$, where $d=$ particle diameter in $\mathrm{mm})$. For size fractions $>3 \varphi$, disposable sieve meshes were used to minimise contamination between samples. Grain size distributions of sample splits comprising particles $>2 \varphi$ were also measured by laser diffraction from a wet dispersion $(\sim 2 \mathrm{~g}$ of sample dispersed in $500 \mathrm{ml}$ MilliQ purified and deionised water) using a Malvern Mastersizer 2000 at the University of Bristol, UK. Volumetric size distributions obtained from laser diffraction were converted to mass distributions assuming a constant density and merged with sieve data using an overlap between $2 \varphi$ and $3 \varphi(125-250 \mu \mathrm{m}$; e.g. Eychenne et al. 2012). For the coarse scoria lapilli deposit at site Q1, the major and minor axes of 100 clasts $<-5 \varphi(>32 \mathrm{~mm})$ were measured in the field over a known area. These measurements were converted to mass assuming ellipsoidal clasts (where the intermediate and short axes were assumed to be equal) and a density of $700 \mathrm{~kg} \mathrm{~m}^{-3}$ (Fig. S3, supplementary information), binned in $\varphi$ intervals (according to the intermediate particle axis) and merged with sieve data using an overlap between $-4 \varphi$ and $-5 \varphi(16-32 \mathrm{~mm})$. Note that the GSD generated by this combined approach still does not include the very largest bombs, which are several tens of centimetres in length, as they could not be statistically sampled within the measurement area.

The total grain size distribution (TGSD) of the hydromagmatic basal fall deposit (not including overlying surge units) was estimated by weighting the GSDs at individual locations by the deposit volume contained between their enclosing isopachs (Murrow et al. 1980; Sparks et al. 1981). Although thickness measurements are numerous and widely distributed, the limited spatial distribution of the 23 locations with corresponding GSDs precludes a robust Voronoi tessellation for TGSD weighting (e.g. Bonadonna and Houghton 2005; Bonadonna et al. 2015). Additionally, as the isopach map of Mattsson and Höskuldsson (2011; Fig. 2b) includes both fall and base surge deposits, TGSD estimates of the fall deposit alone required that we deconvolve the thinning behaviour of the fall and surge deposits (Fig. 4a; Table S2, supplementary information). Thinning of the total deposit is well described by two straight-line segments on a semi-log plot of thickness vs. (isopach area) ${ }^{1 / 2}$ (Fig. 4b; Pyle 1989; Fierstein and Nathenson 1992). Thinning of the fall deposit alone, however, can be approximated by a single straight-line segment (Fig. 4b), which we use to calculate TGSD. Detailed methods are presented in Appendix 1 (supplementary information).

Bulk volumes of hydromagmatic deposits were calculated by integrating beneath both single-segment (basal fall unit only) and two-segment (fall and surge units) thinning relationships using AshCalc software (Fig. 4b; Daggitt et al. 2014), according to the method of Fierstein and Nathenson (1992). The uncertainties on the calculated volumes are estimated conservatively to be $\sim 10 \%$ (Engwell et al. 2013); compaction and erosion are not accounted for. The volume of the cone edifice was calculated geometrically by approximating the morphology as two polygonal frustrums, with dimensions measured from GoogleEarth imagery and cross-sectional profiles (Fig. S1, supplementary information).

\section{Image acquisition}

Sieved size fractions $(-2 \varphi$ to $>5 \varphi$; equivalent to 4 to $<0.032 \mathrm{~mm}$ ) were mounted separately in epoxy grain mounts, ground and polished, then carbon-coated and analysed at the University of Bristol using a Hitachi 
S-3500N scanning electron microscope (SEM) operating in backscattered electron (BSE) mode. BSE-SEM image mosaics of 20-40 images were acquired for each sample size fraction using a working distance of $\sim 18.0 \mathrm{~mm}$ $(z=20 \mathrm{~mm})$ and a $15 \mathrm{kV}$ accelerating voltage. The acquisition magnification was optimised for each grain-size fraction following Liu et al. (2015a) to ensure that the pixel density of each particle remained comparable between images of different size fractions (and above the critical pixel density of $\sim 1000$ pixels/particle). Additional image mosaics of individual clasts (19 clasts in the 1-2 $\mathrm{mm}$ size fraction, one clast in the $2-4 \mathrm{~mm}$ size fraction and the quenched rim of one 16-32 $\mathrm{mm}$ lapillus) were obtained at magnifications of either $\times 100$ or $\times 250$ (equivalent to resolutions of 555 and 1953 pixels $/ \mathrm{mm}$, respectively) for textural quantification.

\section{Componentry}

Using BSE-SEM image mosaics, > 200 ash particles per sample size fraction were manually categorised into component classes using criteria related to the particle outline, bubble texture, crystal texture and juvenile/nonjuvenile character. The minimum sample size of 200 particles was defined by a sensitivity analysis in which we calculated the relative proportions of each component in randomly generated subsamples of progressively larger size (from 1 to the total size of the dataset) and identified the sample size above which the variation in componentry became negligible (Fig. S2, supplementary information).

Total componentry distributions (TCDs) were determined for both hydromagmatic (basal fall only) and magmatic deposits by averaging the proportions of each ash component across all samples at each grain size, and weighting the contribution of each grain-size fraction according to the TGSD. This approach requires that (a) the variation in componentry between samples from different locations is small with respect to the variation between grain sizes and (b) component proportions remain constant for all size fractions $>5 \varphi$ and $<0 \varphi$, as demonstrated in the "Sample descriptions and componentry" section. For the magmatic Jarðbaðshólar deposit, where a TGSD has not been determined, each grain-size fraction is weighted based on a proximal grain size distribution from site Q1 (Fig. 2). This grain size distribution does not account for clast sizes larger than $-5 \varphi(32 \mathrm{~mm})$; incorporation of larger size fractions would skew the distribution further towards larger grain sizes but would have little effect on the TCD, as all size fractions greater than $0 \varphi$ are dominated by a single component class.

\section{Density measurements}

Variations in particle density over the full range of available size fractions were determined for four samples (sites 2.3, 9.3, 7.5, Q1; Table 1). For particles $>-3 \varphi(<8 \mathrm{~mm})$, the average particle density in each grain-size fraction was determined by water pycnometry, using a $0.5 \mathrm{dm}^{3}$ borosilicate pycnometer, de-ionised water and $1 \mathrm{~g}$ of sample per measurement (following the method of Eychenne et al. 2012). Measurements were repeated three times, and the resulting densities averaged. Average particle densities within individual size fractions are reproducible, with standard deviations generally $<50 \mathrm{~kg} \mathrm{~m}^{-3}$. Densities of individual lapilli within the $-3 \varphi(8-$ $16 \mathrm{~mm}$ ) size fraction were calculated from measurements of clast weight in air and in water, wrapped in parafilm wax paper (e.g. Houghton and Wilson 1989). As shown in Figure S3 (supplementary information), our sample size of 45 measurements is sufficient to characterise the density distribution.

Table 1 Details of the main samples used in this study

\begin{tabular}{|c|c|c|c|c|c|}
\hline Sample name & Origin & Deposit type & $\begin{array}{l}\text { GPS location } \\
(\mathrm{min} / \% / \mathrm{s})\end{array}$ & $\begin{array}{l}\text { Distance from } \\
\text { the vent }{ }^{\mathrm{a}}(\mathrm{km})\end{array}$ & Measurements \\
\hline $\mathrm{H}_{2.3}$ & Hydromagmatic & Fall & $\begin{array}{l}653539.6 \mathrm{~N} \\
165138.3 \mathrm{~W}\end{array}$ & 1.5 & Grain size, density, geochemistry, shape, componentry, texture \\
\hline $\mathrm{H}_{6.3}$ & Hydromagmatic & Fall & $\begin{array}{l}653757.4 \mathrm{~N} \\
165038.0 \mathrm{~W}\end{array}$ & 3.5 & Grain size, density, geochemistry, shape, componentry \\
\hline $\mathrm{H}_{9.3}$ & Hydromagmatic & Fall & $\begin{array}{l}653836.1 \mathrm{~N} \\
165217.6 \mathrm{~W}\end{array}$ & 4.5 & Grain size, density, geochemistry, shape, componentry \\
\hline $\mathrm{H}_{7.5}$ & Hydromagmatic & Fall & $\begin{array}{l}653925.6 \mathrm{~N} \\
163402.0 \mathrm{~W}\end{array}$ & 15 & Grain size, density, geochemistry, shape, componentry \\
\hline $\mathrm{M}_{\mathrm{Q} 1}$ & Magmatic (dry) & Fall & $\begin{array}{l}653755.2 \mathrm{~N} \\
165059.4 \mathrm{~W}\end{array}$ & 0.4 & Grain size, density, geochemistry, componentry, texture \\
\hline $\mathrm{M}_{6.3}$ & Magmatic (dry) & Fall & $\begin{array}{l}653757.4 \mathrm{~N} \\
165038.0 \mathrm{~W}\end{array}$ & 0.5 & Grain size, geochemistry, componentry \\
\hline
\end{tabular}

${ }^{a}$ Distance from centre of Jarðbaðshólar vent if magmatic or Hverfjall vent if hydromagmatic 


\section{Textural analysis}

Vesicle textures were quantified from 2D BSE-SEM image mosaics using ImageJ image processing software. BSE-SEM images were manually cleaned to remove particles from inside vesicles and thresholded to separate vesicles, crystals and glass. Vesicle areas were converted into circular equivalent diameters $(\mathrm{EqD}=2 \sqrt{\pi A}$, where $A$ is the measured vesicle area) and binned into lognormal size classes in $1 / 2 \varphi$ increments. The use of lognormal size bins (instead of geometric bins; e.g. Sahagian and Proussevitch 1998) enables direct comparison of vesicle size distributions with log-based $(\varphi)$ granulometric measurements. Lognormal $(1 / 2 \varphi)$ size bins yield comparable 3D distributions to geometric or linear size bins (sensitivity study presented in Appendix 2, supplementary information), with the advantage that comparisons between vesicle size distributions and grain size/componentry/density distributions are not biased by differences in how the data are binned. The minimum area cut-off for vesicle measurements was set to $5 \mu \mathrm{m}^{2}(\mathrm{EqD}=2.5 \mu \mathrm{m})$. The number of vesicles in each lognormal size class was normalised by the vesicle- and crystal-free melt area to give 2D number densities, $\mathrm{N}_{\mathrm{a}}\left(\mathrm{mm}^{-2}\right)$. The equivalent $3 \mathrm{D}$ number densities, $\mathrm{N}_{\mathrm{v}}\left(\mathrm{mm}^{-3}\right)$ and vesicle volume distributions (VVDs) were calculated using stereological methods (following Mangan et al. 1993; Klug et al. 2002; see Appendix 2 for detailed methods). Total bubble number densities (BNDs) were calculated by summing $\mathrm{N}_{\mathrm{v}}$ values across all size classes $>8 \mu \mathrm{m}$ (following Murtagh and White 2013), for comparison with other studies.

\section{Deposit characteristics and stratigraphy}

\section{Hydromagmatic deposits}

\section{Hverfjall edifice}

A vertical cross-section through $87.5 \mathrm{~m}$ of the edifice stratigraphy is exposed on the interior of the western flank of the tuff ring (site 5.11; Fig. 2c) and is illustrated in (Fig. S4a,b, supplementary material). The deposits comprise moderately indurated lapilli-rich beds with a partially palagonised fine ash matrix and are highly heterogeneous in grain size and sorting throughout the section (Fig. S4c-g). Individual beds are often laterally discontinuous (Fig. S4e); cross-bedding structures are occasionally visible, most commonly in the well-sorted fine-grained ash beds. Lapilli include abundant cored accretionary pellets or coated grains, which comprise dense lithic or scoria fragments surrounded by a fine ash coating (Fig. S4d).

Dense lithic blocks and juvenile bombs up to several tens of centimetres diameter occur throughout the exposed sequence and are accompanied by sediment deformation structures. Large (= $1 \mathrm{~m})$ angular blocks of dense basaltic basement are ubiquitous within the crater area (Fig. S4a,b, supplementary information) and define a proximal ballistic field outside of the crater; blocks of $\sim 0.5 \mathrm{~m}$ in diameter are found at radial distances of $\leq \sim 1.5 \mathrm{~km}$ from the crater centre. The wide range of lithic diameters observed at all distances from the vent up to $\sim 1.5 \mathrm{~km}$ suggests that blocks were ejected at a range of velocities and ejection angles. Ballistic modelling using Eject! software (Mastin 2001; input parameters summarised in Table S3) yields an initial ejection velocity of $\sim 160 \mathrm{~ms}^{-1}$ and ejection angles of $30^{\circ}-45^{\circ}$ for a clast of $0.5 \mathrm{~m}$ diameter and a density of $2500 \mathrm{~kg} \mathrm{~m}^{-3}$ to reach $1.5 \mathrm{~km}$ (Fig. S5). Ejection angles outside this range either require much higher initial velocities $\left(\sim 200 \mathrm{~ms}^{-1}\right)$ or trajectories that are too shallow for the clast to surmount the existing crater rim. Notably, a minimum initial velocity of $100 \mathrm{~ms}^{-1}$ is required to eject a block of any size beyond the current crater rim.

\section{Medial to distal deposits}

The opening phase of hydromagmatic activity produced a fine-grained black fall deposit that can be traced to $\leq 20 \mathrm{~km}$ and $1 \mathrm{~cm}$ thickness (Sæmundsson 1991; Mattsson and Höskuldsson 2011). This basal pyroclastic fall unit is generally massive, although the base is finergrained at thicker $(20-30 \mathrm{~cm})$ proximal localities (e.g. sites 6.3 and 9.3).

The overall stratigraphic trends are illustrated in Fig. 5. The initial fall deposit is overlain by base surge deposits emplaced asymmetrically to the N-NE of the Hverfjall vent (Fig. 3c-f). A maximum deposit thickness of $\sim 7 \mathrm{~m}$ was recorded at site 4.7 , $1.8 \mathrm{~km} \mathrm{NE}$ of the vent. Surge deposits thicken into topographic depressions, form pinch and swell structures with significant lateral thickness variations over small distances and erode to produce characteristic circular landforms (Fig. 3c). Basal surge units are very poorly sorted massive lapilli tuff, with abundant dense angular lapilli and occasional blocks and bombs within an ash-rich matrix (Figs. 3). Juvenile bombs of $\sim 5-40 \mathrm{~cm}$ deform the underlying bedding, reflecting ballistic emplacement into wet cohesive sediment (Fig. 3g). Tree moulds produced by plastering of wet cohesive sediment against tree trunks are inclined directly away from the Hverfjall vent (Einarsson 1982; Pórarinsson 1952; Fig. 3h). Where the lower contact is exposed, this basal unit is often underlain by a thin $(\leq 1 \mathrm{~cm})$ exposure of the fine-grained black fall deposit, which lies directly above the white silicic Hekla-3 marker bed. The basal massive lapilli tuff unit is not observed at distances greater than $3.3 \mathrm{~km}$ from the Hverfjall vent, even where the basal surge contact is exposed. Sedimentary flow structures include low-angle cross-bedding, antidunes and flute casts (Fig. 3d, i), and indicate highly variable flow conditions. Lapilli are often concentrated in discontinuous 


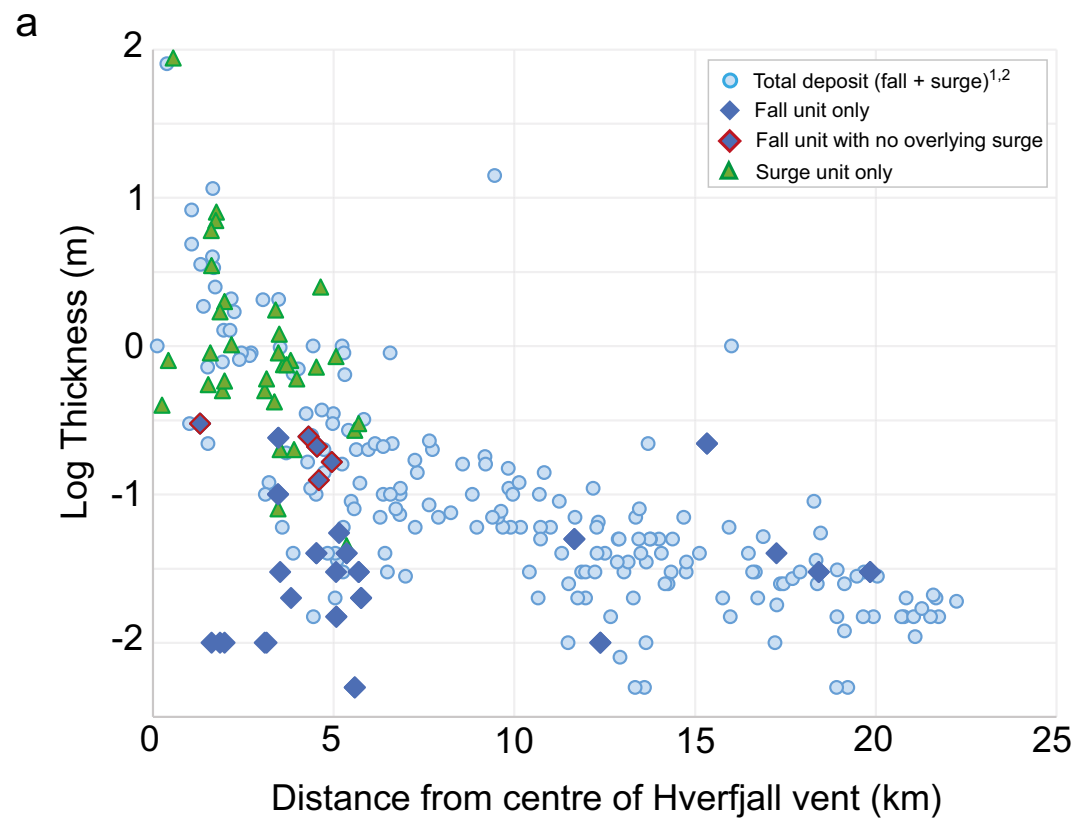

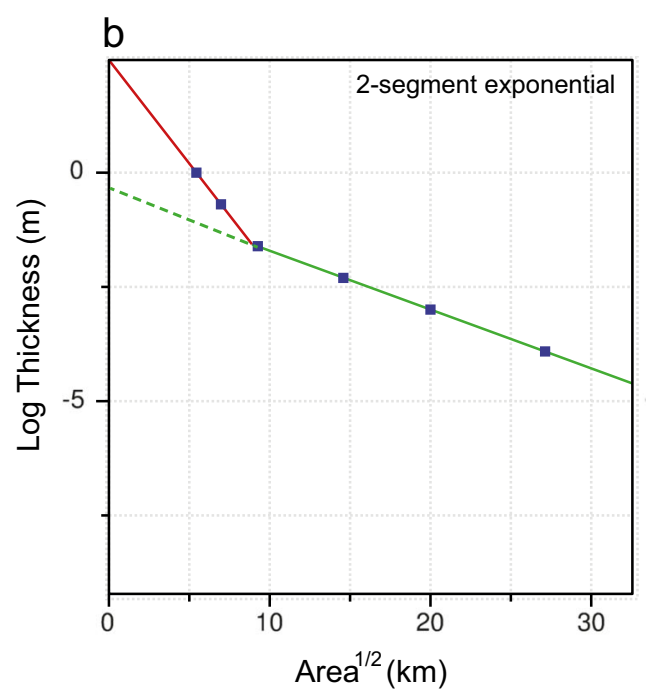

Fig. 4 a, b Deposit thinning as a function of distance, expressed in the form of the Area ${ }^{1 / 2}$ of the enclosing isopach. Circular symbols correspond to the isopach contours for the hydromagmatic deposit (from Mattsson and Höskuldsson 2011), coloured according to whether the thickness includes both fall and surge units (orange) or fall only (blue). The thinning relationship can be well described by a two-segment exponential, with the inflexion point occurring at the maximum distal

lenses. The sedimentological character of base surge deposits varies laterally.

Above the wet basal surge are clast-supported beds of ashcoated lapilli and coarse ash intercalated with thinly laminated beds of fine to moderately coarse ash (Fig. 5). These stratified lapilli tuffs are found to distances of $5.5 \mathrm{~km}$, the distal exposure limit of the surge units. The uppermost units are dominated by accretionary lapilli tuff, with well-sorted clast-supported layers of either lapilli- or coarse ash-sized aggregates (spherical coated particles and AP1 and AP2 accretionary pellets, following the

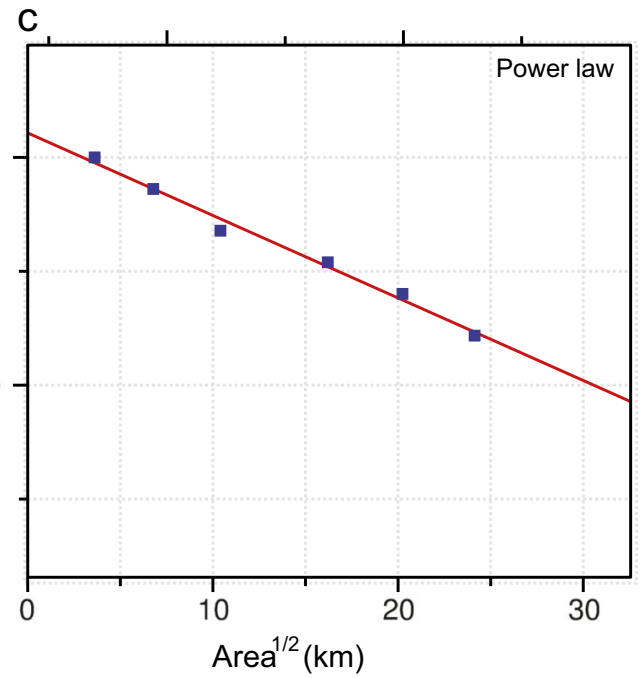

extent of the surge deposits. Crosses correspond to fall/surge thickness measurements from individual outcrops made during this study, with their relative position on the $\mathrm{x}$-axis determined by the Area ${ }^{1 / 2}$ of their enclosing isopach. Again, symbol colour indicates whether surge deposits were present or absent in the sequence. When fall thickness is decoupled from total thickness (fall + surge), the thinning relationship can be described by a single-segment exponential

terminology of Brown et al. 2012) separated by thinly laminated fine ash horizons (Figs. 3e and 5). Beds thin upwards to minimum thicknesses of $\sim 1 \mathrm{~cm}$ and $\sim 1 \mathrm{~mm}$ for the lapilli-rich and lapilli-poor layers, respectively. Thinly bedded ash-rich intervals become dominant (relative to lapilli-rich beds) and are progressively less consolidated with increasing transport distance.

The total bulk volume of hydromagmatic deposits (both fall and surge units) is $0.15 \pm 0.02 \mathrm{~km}^{3}$, of which the basal fall unit comprises $0.08 \pm 0.01 \mathrm{~km}^{3}$. The combined volume of the deposits and the Hverfjall edifice gives a total erupted 
volume of $0.27 \pm 0.03 \mathrm{~km}^{3}$, at the high end of the range of $10^{-4}$ to $10^{-1} \mathrm{~km}^{3}\left(10^{5}-10^{9} \mathrm{~m}^{3}\right)$ characteristic of tuff cone/tuff ring-forming eruptions (White and Ross 2011).

\section{Magmatic deposits}

The Jarðbaðshólar scoria cone complex is situated directly north of the Hverfjall tuff ring along the same fissure (Fig. 2) and comprises multiple nested cones of different ages. Eruptive activity at Jarðbaðshólar during the Hverfjall Fires appears to have been concentrated at a single vent, which produced lapilli-dominated scoria fall deposits and lava flows. Scoria lapilli units have a limited dispersal distance $(1.3 \mathrm{~km})$, with most of the deposit mass restricted to the cone edifice itself.

The cone edifice comprises outwardly dipping units of scoria lapilli fall (Fig. S6a, supplementary information). Cone-forming deposits are generally massive, with alternating units of thick scoria lapilli and thinner horizons of welded spatter (Fig. S6b). Generally, the base of each scoria lapilli unit comprises relatively fine, well-sorted lapilli; pyroclasts are typically highly vesicular with irregular, angular morphologies bounded by both fluidal and brittly fractured exterior surfaces. Units are inversely graded over 2 to $4 \mathrm{~m}$, with upper sections comprising both coarse angular lapilli (often with fluidal surfaces) and fluidal bombs flattened parallel to bedding. Bombs are typically $<30 \mathrm{~cm}$ along their longest axis, but can reach $\sim 70 \mathrm{~cm}$. The upper contact between each spatter horizon and the overlying fine scoria lapilli unit is generally abrupt.

A massive, clast-supported pyroclastic fall deposit composed of fine scoriaceous lapilli extends to $1.3 \mathrm{~km}$ north of the Jarðbaðshólar vent, almost twice the $0.7 \mathrm{~km}$ maximum extent previously suggested (Mattsson and Höskuldsson 2011). This fall unit thins rapidly from $>5 \mathrm{~m}$ at $0.2 \mathrm{~km}$ (site Q3) to $2.5 \mathrm{~cm}$ at $1.3 \mathrm{~km}$ (site 9.3). The cone active during the Hverfjall Fires is breached on both eastern and western flanks, and the lava flows can be traced to these breaches. Lava flows travelled towards the east, except a single flow to the west. The contact between lava flow units and magmatic fall deposits is exposed in a fault $0.5 \mathrm{~km}$ E-SE of the Jarðbaðshólar cone, where a single lava flow unit (up to $2.5 \mathrm{~m}$ thick at site 3.8 ) stratigraphically overlies the magmatic fall deposit (Fig. S6c, d). Here, the base of the lava flow is in contact with the underlying scoria lapilli deposit, the top of which is welded and flattened by the heat of the overlying flow. The temporal evolution from explosive to effusive activity at Jarðbaðshólar is similar to the behaviour documented at other monogenetic scoria cones (e.g. Heimaey, Iceland; Self et al. 1974; Lathrop Wells, S. Nevada; Valentine et al. 2005, 2007) and likely reflects waning mass flux.

\section{Stratigraphic relationships between magmatic and hydromagmatic deposits}

The four deposit types-hydromagmatic fall, hydromagmatic surges, magmatic fall and lava flowsare rarely observed together because of the limited spatial extent of the magmatic units. Nevertheless, several exposed sections show magmatic scoria and/or lava flow units either intercalated within hydromagmatic surge units or directly overlying the basal hydromagmatic fall deposit (Figs. 5 and S6d). Unusually, however, an exposure $0.5 \mathrm{~km}$ south of the Jarðbaðshólar vent (site 4.1; Fig. 2c) shows vesicular scoria lapilli at the basal contact between the underlying Hekla-3 deposit and the lowermost thin hydromagmatic fall unit from the Hverfjall vent. Coarse lapilli, up to several centimetres in size, were also observed throughout the overlying $60 \mathrm{~cm}$ surge sequence, distributed both within and between individual surge beds, suggesting on-going contemporaneous deposition.

Stratigraphic relationships support previous interpretations that magmatic and hydromagmatic vents were active contemporaneously (Mattsson and Höskuldsson 2011). Although sections at medial sites (6.3 and 9.3) suggest that the deposition of hydromagmatic material (both pyroclastic fall and base surges) began prior to the onset of magmatic fall (Fig. 5), the presence of coarse scoria lapilli directly above Hekla-3 in more proximal sections (4.1) indicates that magmatic and hydromagmatic vents may instead have initiated near-synchronously. However, the early phase of activity at Jarðbaðshólar was probably restricted to proximal conebuilding and, therefore, did not contribute to the wider tephra blanket. The observed stratigraphic relationships between lava flow units and magmatic fall (both proximal cone-forming and medial deposits) suggest that lava flow emplacement occurred late in the eruptive history of the Jarðbaðshólar vent, after the main phase of cone construction. The presence of finely stratified surge deposits overlying magmatic fall and lava flow units, even in proximal locations, indicates that explosive activity continued at the Hverfjall vent after activity ceased at Jarðbaðshólar, thereby demonstrating the longevity of the hydromagmatic activity.

\section{Ash characterisation}

\section{Granulometry}

Grain size distributions (GSDs) differ markedly between hydromagmatic (Hverfjall tuff ring) and magmatic (Jarðbaðshólar) deposits, with hydromagmatic deposits consistently finer-grained (Fig. 6; Table S4). Ash-sized material $(>-1 \varphi$ or $<2 \mathrm{~mm}$ ) comprises $>89 \%$ of the total mass of hydromagmatic samples (basal fall unit), with up 


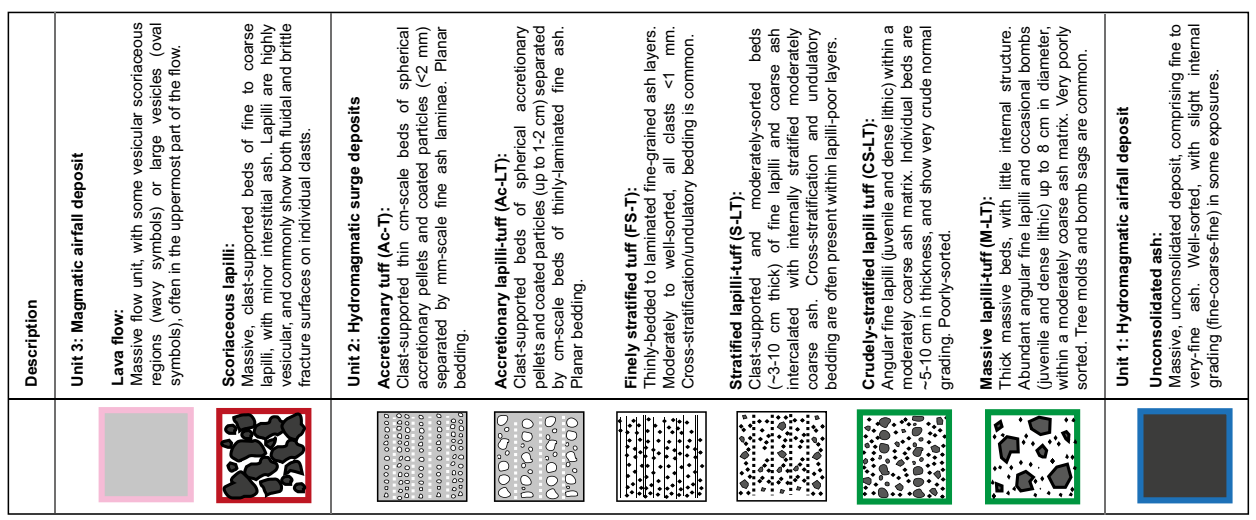

$\infty 00$

政

웅

웅

突 苛

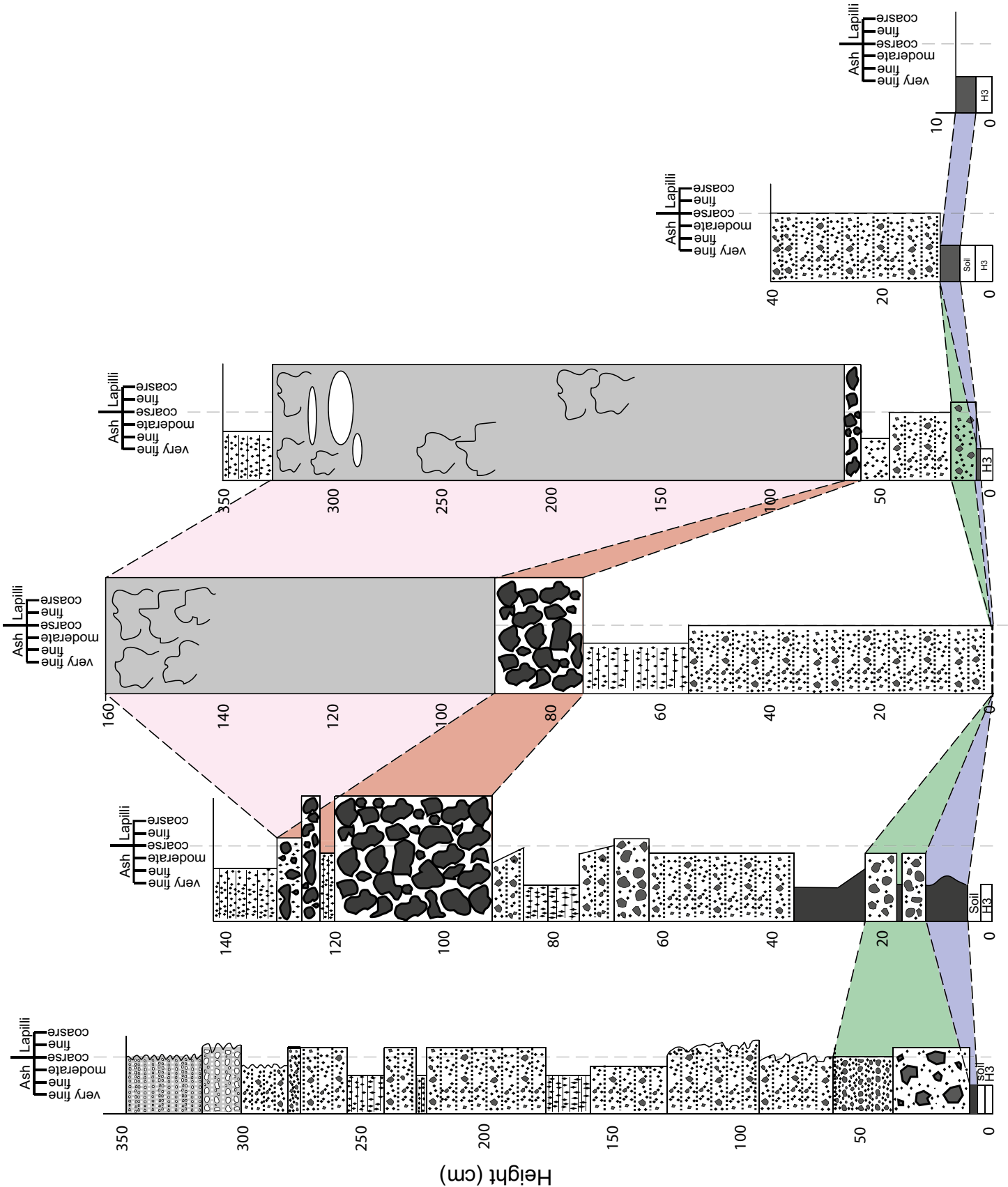


Fig. 6 Grain size distributions (GSDs) for the deposits of the Hverfjall Fires. Note that GSDs refer to size distributions at specific locations, while total grain size distributions (TGSDs) incorporate many individual GSDs from different locations. a GSDs for the Hverfjall hydromagmatic fall unit (coloured according to distance from the Hverfjall vent) and the magmatic scoria deposit (black and grey lines, where the black line represents the full reconstructed proximal GSD). Dashed lines correspond to the GSDs of mixed deposits of both hydromagmatic and magmatic pyroclasts, and are typically bimodal. b TGSDs for Hverfjall (dark blue symbols) and Jan Mayen (grey symbols; Gjerløw et al. 2015) are compared to distal hydromagmatic GSDs for Hverfjall (site 6.4; light blue symbols) and Grímsvötn, Iceland (50-115 km from the 2011 vent; Liu et al. 2015b). A proximal magmatic GSD for Jardbadsholar (site Q1; red symbols) is compared to the TGSD for Kīlauea Iki, Hawaii (Parfitt 1998). Grey-shaded field highlights the range of typical GSDs for proximal deposits from other hydromagmatic eruptions $(<1 \mathrm{~km}$ from the vent; from Liu et al. 2015b)
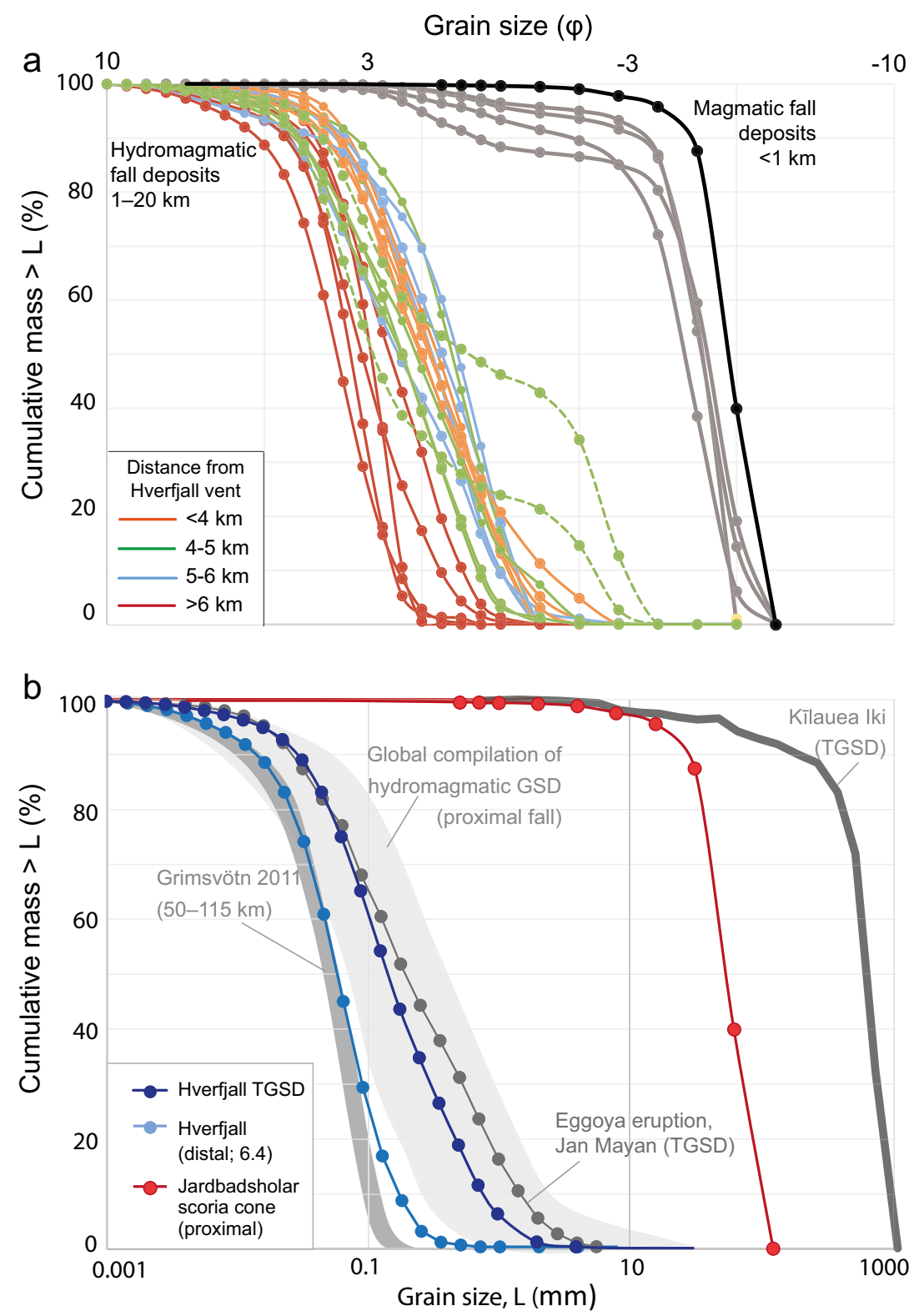

to $55 \%$ fine ash $(>4 \varphi$ or $<63 \mu \mathrm{m})$ for the most distal samples. The total grain size distribution (TGSD) for the basal fall deposit comprises $97 \%$ ash-sized material, with $20 \%$ fine ash (dark blue line on Fig. 6b). With increasing distance from the Hverfjall vent, the median grain size of hydromagmatic fall deposits decreases from $1.1 \varphi$ to $4.2 \varphi$ (accompanied by an increase in sorting; Fig. S7, supplementary information). In contrast, the median grain sizes of magmatic fall deposit samples are between $-4.7 \varphi$ and $-5.8 \varphi$ with ash-sized material comprising $<12 \%$ of the mass. Where hydromagmatic fall and magmatic scoria are observed together, GSDs are bimodal (dashed green curves; Fig. 6a), suggesting contemporaneous deposition and mixing.

\section{Sample descriptions and componentry}

Ash particles from both hydromagmatic and magmatic deposits are almost entirely glassy (sideromelane), with minor phenocrysts of plagioclase, olivine and clinopyroxene (Fig. 7). Phenocrysts occur as individual crystals, but are more common within crystal aggregates or intergrowths. Many crystals, particularly olivine, exhibit moderately to highly skeletal morphologies indicative of rapid growth (Fig. 7a, b). Incorporation of recycled clasts into large ash particles and lapilli is relatively common, with recycled clasts distinguished by their microcrystalline texture that contrasts with the host sideromelane grain (Fig. 7c). The boundaries between recycled clasts and the host 

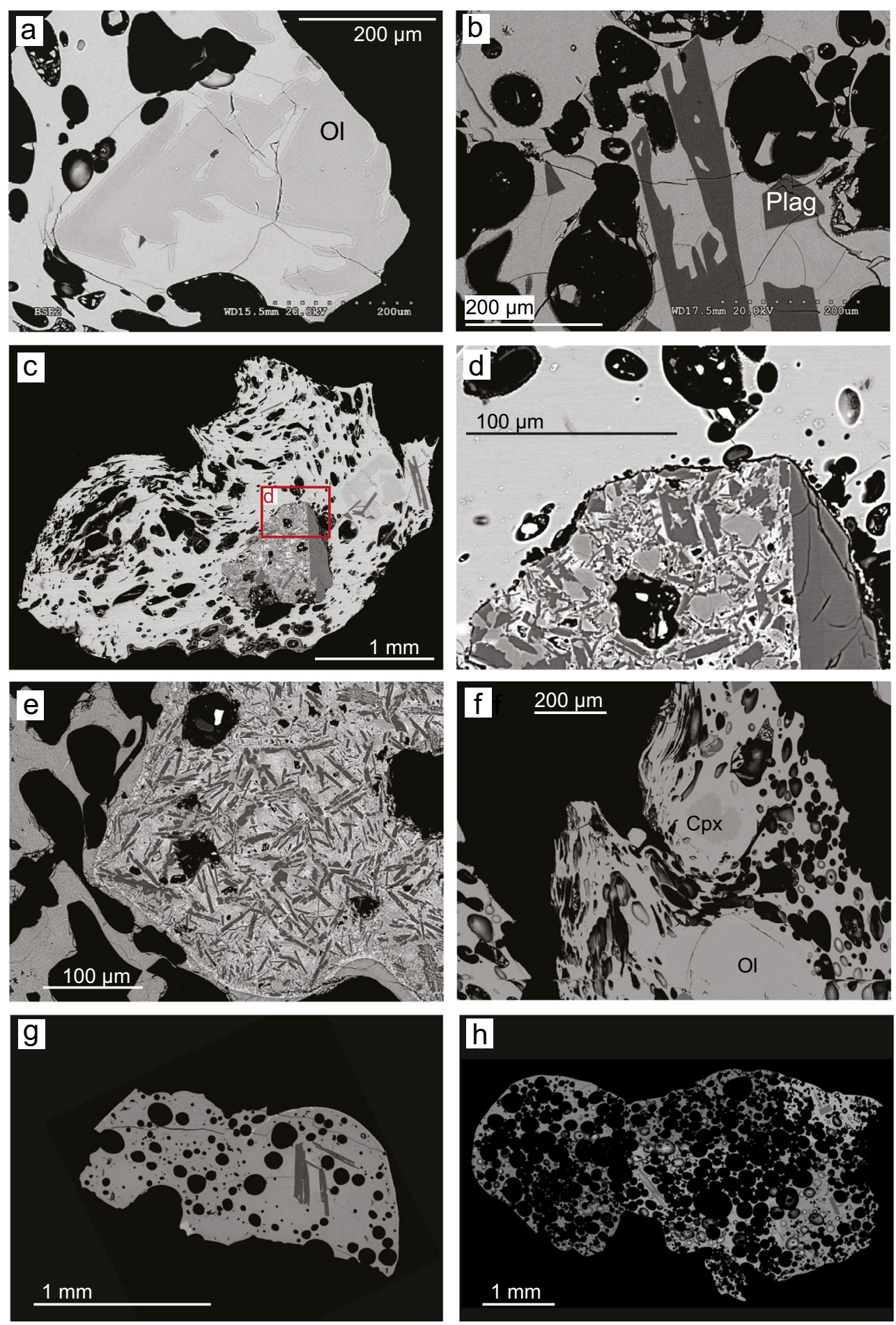

Fig. 7 Crystal and bubble textures in hydromagmatic pyroclasts [sample site 2.3]. Skeletal morphologies of a olivine [ol], b plagioclase [plag] and minor clinopyroxene phenocryst phases are indicative of rapid growth. $\mathbf{c}$ Composite clasts are common, particularly for coarse ash and lapilli, where recycled crystalline lithics (cognate and/or accessory) are incorporated into juvenile sideromelane clasts. The boundaries between recycled clasts and the host matrix are often sharp and demarcated by $\mathbf{d}$

vesicle void space or e rims of oxide crystals. f Although most bubbles are preserved as spherical vesicles, some pyroclasts preserve sheared and deformed bubbles indicative of rapid quenching faster than the relaxation time of low viscosity basaltic melt. Deformation often occurs around phenocryst phases. $\mathbf{g}, \mathbf{h}$ Particles sometimes exhibit either partial or complete fluidal rims, characteristic of viscous deformation

Particles were categorised into six component classes matrix are sharp and often delineated either by oxide rims (Fig. 7e) or a thin rim of void space (Fig. 7d). based on criteria related to the particle outline, bubble texture, 
crystal texture and juvenile/non-juvenile character: (1) dense fragments, (2) vesicular particles, (3) shards, (4) microcrystalline grains, (5) free crystals and (6) lithic grains (Table S5, supplementary information). Dense fragments are poorly vesicular (0-20\% internal vesicles by area) and angular with planar surfaces, and comprise both thin plates and, more commonly, equant blocky grains. Exterior surfaces commonly display stepped fracture patterns with characteristic distributary branching ('river-lines') that indicate brittle fracturing under mixed-mode stresses (Hull 1999). Shards are characterised by highly concave outlines with smooth surfaces from large bounding vesicles. Internal vesicles are few or absent. Vesicular particles have internal vesicles that comprise $\geq 20$ to $\sim 75 \%$ by area. Apparent $2 \mathrm{D}$ bubble wall thicknesses range from $\sim 50 \mu \mathrm{m}$ to just a few microns for the most vesicular clasts. Vesicles are mostly round in cross-section, but may be strongly deformed in larger particles (coarse ash and lapilli; Fig. 7c, f). Particle outlines are typically angular, with scalloped edges formed by bounding vesicles with diameters much smaller than the particle, although a small proportion of coarse ash grains show either partial or complete fluidal outer surfaces (Fig. 7g, h). Microcrystalline grains contain small plagioclase microlites within a glassy matrix and are poorly to moderately vesicular. Where present, vesicles are irregular in shape and often deformed around crystals. Free crystal particles include both crystal fragments and intact crystals, which are often coated with a thin rim of dense glass. Lithics represent the non-juvenile component derived from erosion of the conduit walls or surrounding country rock and are typically holocrystalline.

The full range of ash components is present in both hydromagmatic and magmatic ash particles over the measured grain size range $(0-6 \varphi)$. Importantly, however, the relative proportions of each component (by number) vary by up to an order of magnitude between different grain-size fractions (Table S5; Fig. 8). In fact, variation in the proportion of

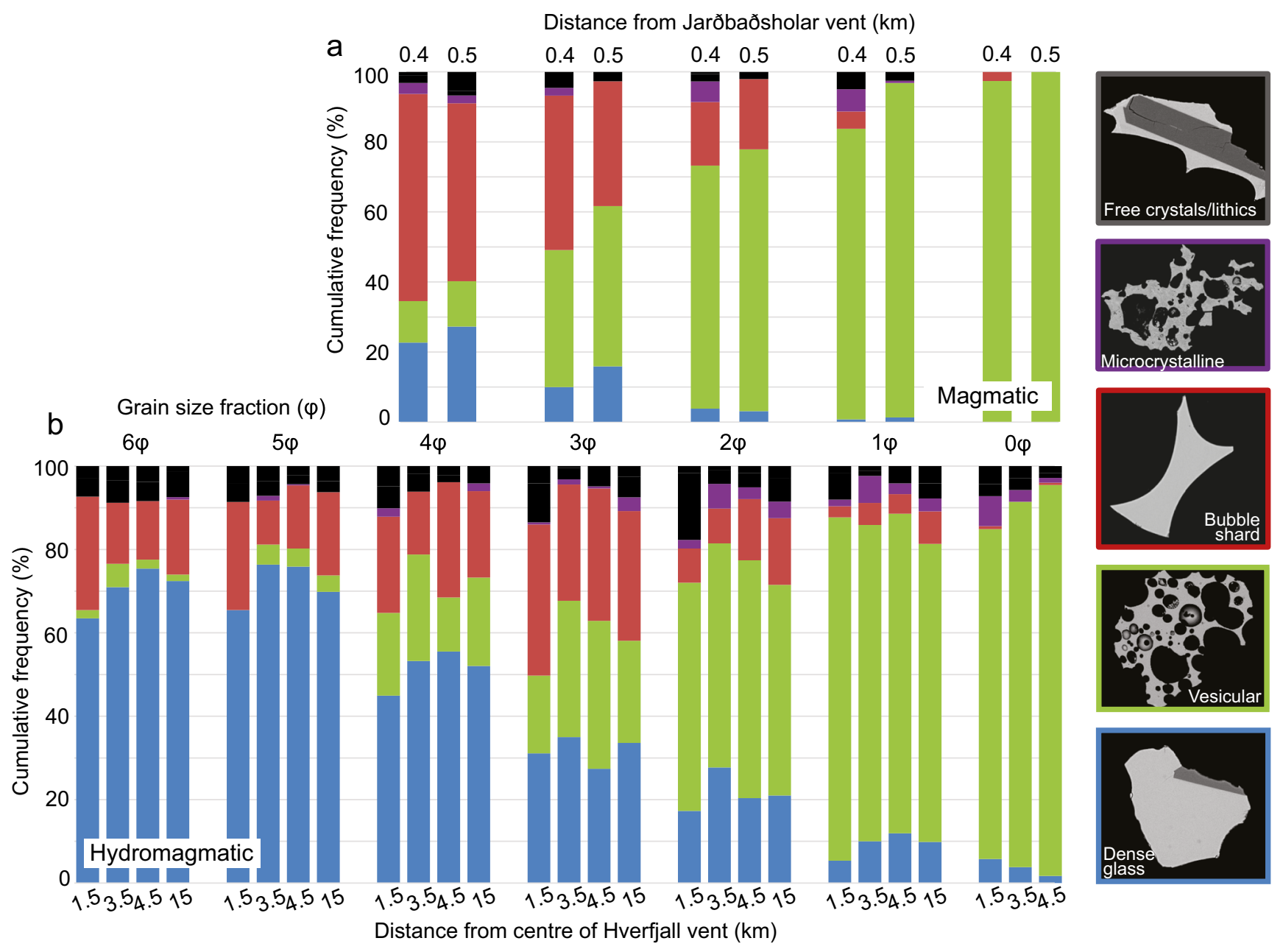

Fig. 8 Variation in the relative proportions of dense glass fragments (blue), vesicular particles (green), shards (red), microcrystalline grains (purple), free crystals and lithic grains (black), as a function of grain size and distance from the vent. a Magmatic deposits at $0.4 \mathrm{~km}$ (cone; site Q1) and $0.5 \mathrm{~km}$ (site 6.3) dispersal distance, over grain sizes of $0 \varphi(1-$
$2 \mathrm{~mm})$ to $4 \varphi(0.063-0.125 \mathrm{~mm})$. b Hydromagmatic fall deposits at 1.5 (site 2.3), 3.5 (site 6.3), 4.5 (site 9.3) and $15 \mathrm{~km}$ (site 7.5) dispersal distance, over grain sizes of $0 \varphi(1-2 \mathrm{~mm})$ to $6 \varphi(0.016$ to $0.032 \mathrm{~mm})$. Inset images: representative backscattered electron SEM images of each component class 
different ash components with grain size is much greater than with distance from the vent. For example, in the hydromagmatic fallout ash examined, the proportion of dense fragments increases approximately linearly from 2 to $3 \%$ (at $0 \varphi$ ) to $61-76 \%$ (at 5 and $6 \varphi$ ). In contrast, vesicular particles decrease in abundance from 80 to $88 \%$ (at $0 \varphi$ ) to $1-3 \%$ (at 5 and $6 \varphi$ ). Component proportions remain relatively constant for the $5 \varphi$ and $6 \varphi$ size fractions (i.e. fine ash $<63 \mu \mathrm{m}$ ). The proportion of shards, in contrast, reaches a maximum abundance of $28-36 \%$ in the $3 \varphi$ size fraction. Together, free crystals and lithic grains are minor components of hydromagmatic ash $(<10 \%$ of each sample size fraction) except in the most proximal sample site 2.3 , particularly within the $2 \varphi$ and $3 \varphi$ grain-size fractions. The proportion of microcrystalline grains is $<6 \%$ of all samples and is almost negligible in the finest size fractions $>2 \varphi$. In magmatic ash samples, vesicular particles comprise almost $100 \%$ of the $0 \varphi$ size fraction, but decrease in abundance to $12-13 \%$ at $4 \varphi$. The relative proportion of dense fragments also increases approximately linearly from 0 to $1 \%$ (at $0 \varphi$ ) to $21-26 \%$ (at $4 \varphi$ ), although the absolute proportions of dense fragments are $\sim 20-30 \%$ less than in hydromagmatic samples at equivalent size fractions. Magmatic samples lack sufficient material finer than $4 \varphi$ $(<63 \mu \mathrm{m})$ for meaningful componentry measurements of the fine ash fraction.

\section{Densities}

Mean particle densities increase with decreasing grain size (Fig. 9). Hydromagmatic samples also show spatial variations in density. Unusually, the most proximal sample (site 2.3; purple line in Fig. 9) has the lowest density particles across all size fractions, particularly for grain sizes $<1 \varphi$. Densities of ash grains in this sample range from $1390(-2 \varphi)$ to $2630(4 \varphi)$ $\mathrm{kg} \mathrm{m}^{-3}$, with a mean density of $2150 \mathrm{~kg} \mathrm{~m}^{-3}$. More generally,

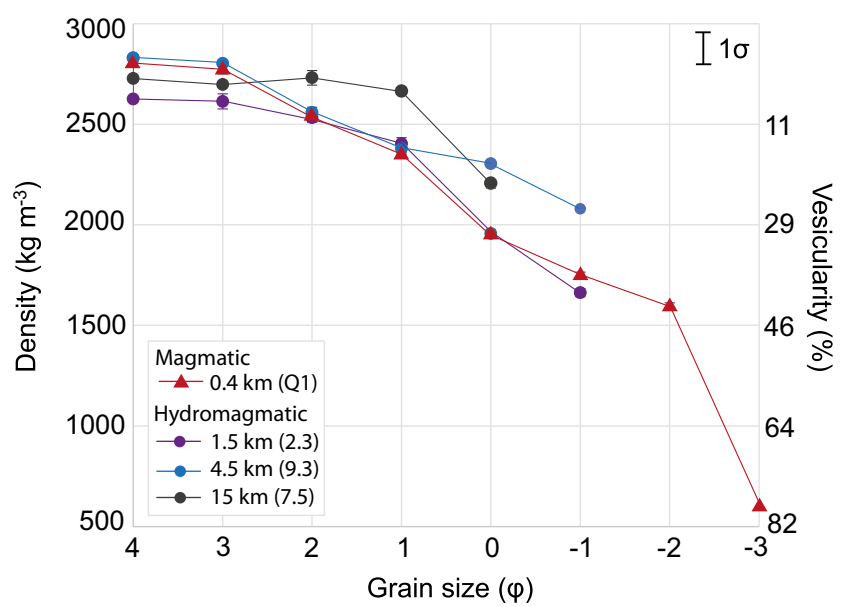

Fig. 9 Average density (and vesicularity) as a function of grain size, for magmatic (triangles) and hydromagmatic (circles) samples. Vesicularity is calculated assuming a dense rock equivalent of $2800 \mathrm{~kg} \mathrm{~m}^{-3}$. Most error bars $(1 \sigma)$ are smaller than the symbol size ash particles reach a maximum density of $2600-2800 \mathrm{~kg} \mathrm{~m}^{-3}$ for grain sizes $>3 \varphi$ (sites 2.3 and 9.3) or $>1 \varphi$ (site 7.5). The size-density relationship of particles in the proximal magmatic sample, site Q1 (red line in Fig. 9), mirrors that of the hydromagmatic deposit to grain sizes of $4 \mathrm{~mm}$, above which the mean particle density decreases substantially to $600 \mathrm{~kg} \mathrm{~m}^{-3}$.

The average particle density is coupled to the abundance of vesicular particles in each size fraction: as the proportion of vesicular particles decreases almost linearly from 75 to $100 \%$ at $0 \varphi$ to $2-10 \%$ for size fractions $>3 \varphi$, density increases concurrently (Figs. 8 and 9). Densities remain constant at a maximum value of $\sim 2700 \mathrm{~kg} \mathrm{~m}^{-3}$ for size fractions $>3 \varphi$, which also corresponds to the grain size below which the abundance of vesicular particles becomes negligible.

\section{Bubble microtextures}

Vesicles in all samples are mostly circular in cross-section (Fig. S8; supplementary information), with minor exceptions where vesicles are elongated and deformed around phenocrysts (e.g. Fig. 7f). Importantly, clast vesicularities overlap in hydromagmatic ( 25 to $75 \%$ ) and magmatic (53 to $74 \%$ ) clasts (Table S6; Fig. 1). Bubble number densities (BNDs) are also comparable for hydromagmatic $\left(1.5 \times 10^{12}\right.$ to $\left.2.5 \times 10^{13} \mathrm{~m}^{-3}\right)$ and magmatic $\left(7.3 \times 10^{12}\right.$ to $\left.1.4 \times 10^{13} \mathrm{~m}^{-3}\right)$ ash particles and overlap over a relatively narrow range (Fig. 1). Although low vesicularity clasts extend the range of hydromagmatic BNDs to lower values, BNDs stabilise at $1.45 \pm 0.5 \times 10^{13} \mathrm{~m}^{-3}$ and are largely independent of vesicularity when $>40 \%$ (Fig. 1). Vesicle textures in the quenched rim of a magmatic lapillus (16-32 mm) also lie within the range measured for ash-sized grains. The smaller bubble size in the rim contrasts with the larger bubbles in the expanded lapillus core.

Vesicle volume distributions (VVDs) in hydromagmatic clasts are unimodal (except for clasts 9 and 10, which have a second mode resulting from a single large bubble) and are relatively symmetrical about the mode (Fig. 10). Modal volumetric vesicle sizes are positively correlated with vesicularity: low vesicularity clasts $(<50 \%)$ generally have a common mode in the $45-63 \mu \mathrm{m}$ size class, moderately vesicular clasts (50-66\%) have a broad mode between 45 and $125 \mu \mathrm{m}$ with a peak in the 91-125 $\mu \mathrm{m}$ size class and high vesicularity clasts (> 70\%) have slightly positively skewed distributions with consistently larger modal vesicle sizes in the $125-180 \mu \mathrm{m}$ size class (Fig. 10). In magmatic clasts, VVDs also vary from the low vesicularity (35\%) quenched lapillus rim, which has a broad mode between 45 and $125 \mu \mathrm{m}$, to high vesicularity clasts $(>55 \%)$ where distributions are positively skewed with a clear mode in either the $125-180 \mu \mathrm{m}$ or $180-250 \mu \mathrm{m}$ size classes.

The calculated VVDs show that our choice of clast size has not truncated the apparent vesicle size distribution. The 


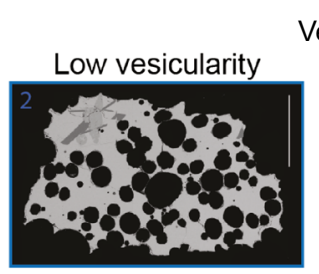

Vesicle volume distribution (VVD)

Moderate vesicularity
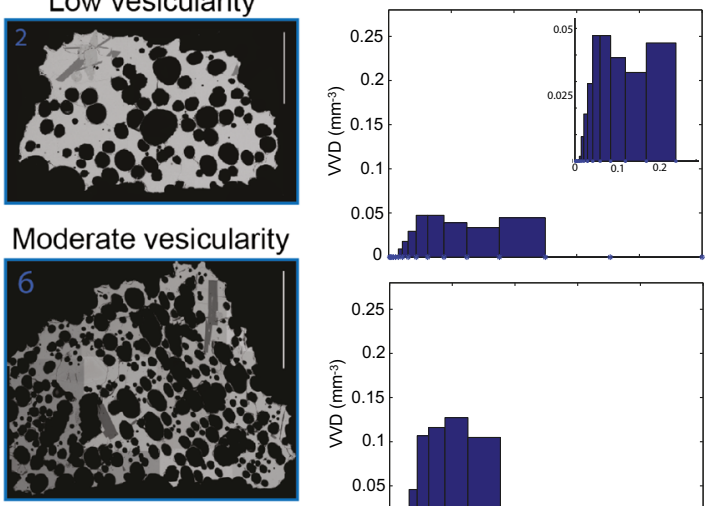

High vesicularity
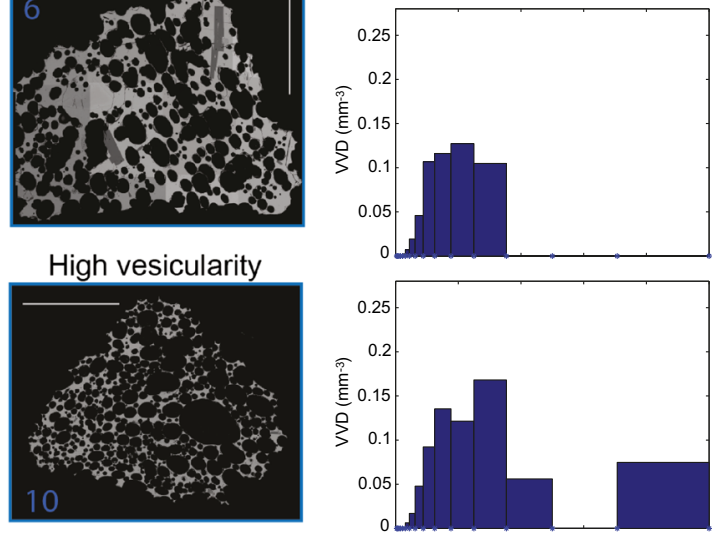

High vesicularity
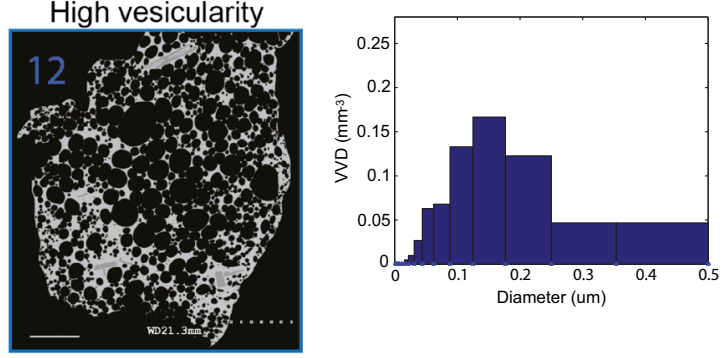

Low vesicularity
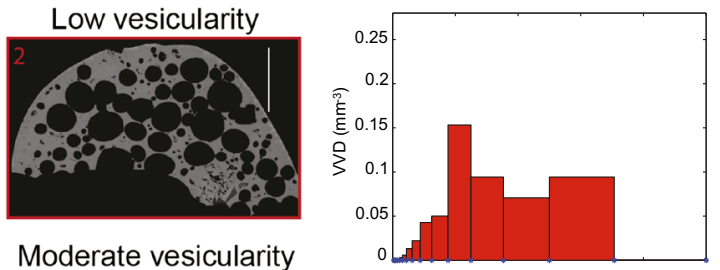

Moderate vesicularity
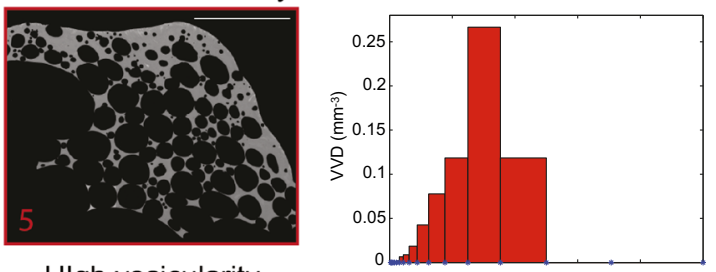

HIgh vesicularity
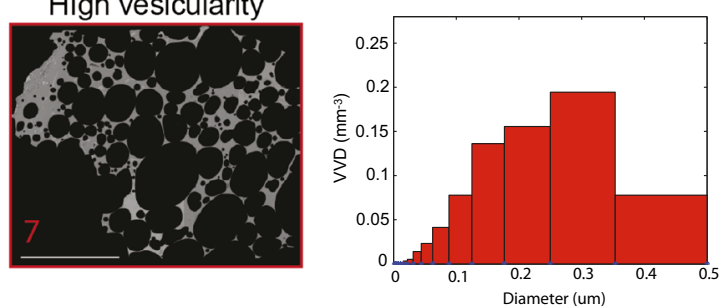

Fig. 10 Vesicle volume distributions (VVD) for representative low, moderate and high vesicularity clasts from hydromagmatic (blue; site 2.3) and magmatic (red; site Q1) deposits. The corresponding vesicularities and bubble number densities for each clast are shown in Fig. 1 maximum vesicle diameter in all clasts is $<500 \mu \mathrm{m}$ (and most are $<250 \mu \mathrm{m}$ ), which is considerably smaller than the radii of the particles analysed. Furthermore, the size range of vesicles preserved in 1-2 $\mathrm{mm}$ ash particles is identical to that in the quenched rim of a 16-32-mm lapillus (Table S6).

\section{Discussion}

The contrasting grain size distributions (GSDs) for hydromagmatic (fall only) and magmatic deposits of the Hverfjall Fires (Fig. 6a) is a recurrent feature of products of wet vs. dry mafic volcanism (Walker and Croasdale 1971; Walker 1971; Houghton and Nairn 1991; Liu et al. 2015b). The greater ash content of hydromagmatic samples reflects elevated fragmentation efficiencies; however, the ash content at a given distance from the vent may be substantially augmented by moisture-induced deposition by aggregation and en masse sedimentation. Therefore, to be meaningful, total grain size distributions (TGSDs) of deposits should be compared, rather than GSDs from individual locations. The TGSD calculated for the Hverfjall hydromagmatic fall deposit lies within the global range of proximal mafic hydromagmatic GSDs (Fig. 6b; compiled by Liu et al. 2015b) and is in good agreement with measurements of the Eggoya eruption of Jan Mayen, which represents the only other estimated TGSD for a tuff cone/tuff ring-forming eruption (Gjerløw et al. 2015). We do not have sufficient data to construct a TGSD from the 'dry' magmatic deposit; however, based on exposures to $1.5 \mathrm{~km}$, we are confident that the ash content is much lower than the hydromagmatic fall unit studied. There are very few TGSDs for cinder cone eruptions, but data from Cerro Negro (Rose et al. 1973), Izu-Oshima (Mannen 2006), Heimaey (Self et al. 1974) and Al-Madinah (Kawabata et al. 2015) suggest that the fine ash content of scoria cone eruptions is negligible, and that most ( $>90-95 \%$ ) of the fragmented material are $>1 \mathrm{~mm}$ in size.

The TGSD produced by an eruption is controlled by the fragmentation process and the characteristic vesicle size (Rust and Cashman 2011). Figure 11 compares the size distributions of particles and bubbles for (a) magmatic and (b) hydromagmatic (fall only) deposits from the Hverfjall Fires. Most strikingly, the size ranges of vesicles and particles overlap for hydromagmatic deposits, but are separated by several orders of magnitude in magmatic deposits. This difference between hydromagmatic and magmatic patterns of vesicle and particle size data is consistent with published data from other magmatic (e.g. Rust and Cashman 2011) and hydromagmatic (e.g. Liu et al. 2015a) eruptions of low $\mathrm{H}_{2} \mathrm{O}$ basalt (see also Fig. 11); it also suggests that fragmentation processes occurring at the Hverfjall and Jarðbaðshólar vents were mechanically distinct. In the following discussion, we integrate observations from a diverse suite of pyroclast 
Fig. 11 Comparison of grain size distributions (GSD; solid lines) and cumulative vesicle volume distributions (VVDs; dashed lines) for $\mathbf{a}$ magmatic and $\mathbf{b}$ hydromagmatic deposits. Shaded regions show the range of VVDs in other mafic eruptions for comparison; *Magmatic lava fountains: Kilauea Iki, Hawaii (Stovall et al. 2011; Stovall et al. 2012; Porritt et al. 2012); Hydromagmatic: Black Point, USA (Murtagh and White 2013), Capelas, Azores (Mattsson 2010) and 2011 Grímsvötn, Iceland (Liu et al. 2015a)
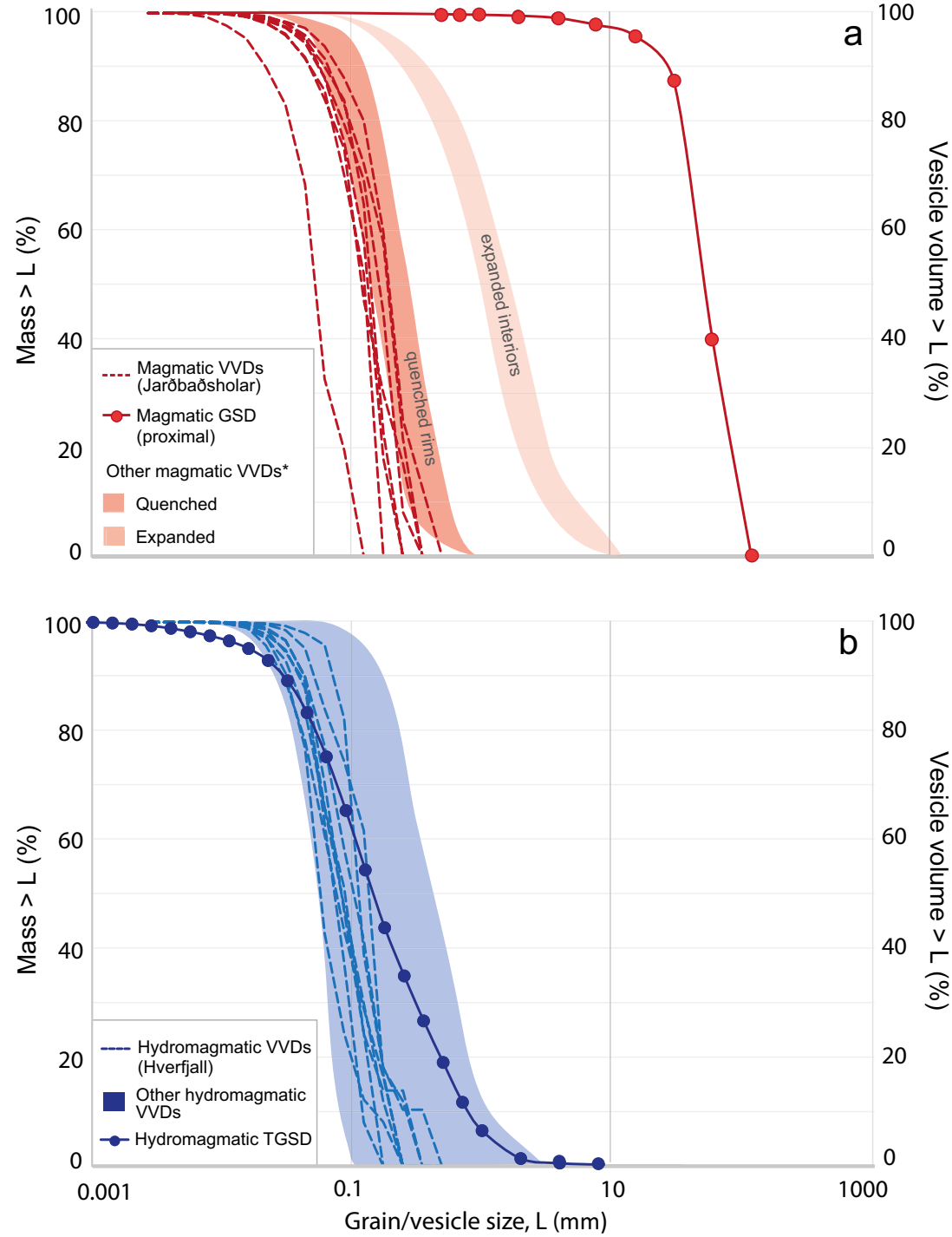

measurements to compare and contrast the eruptive processes operating at magmatic and hydromagmatic vents during the Hverfjall Fires.

\section{How do particle sizes, shapes and textures co-vary?}

The physical properties of erupted pyroclasts record the magmatic conditions prior to and during fragmentation; if unmodified by post-fragmentation processes, particle shape preserves information about the fragmentation regime (i.e. brittle vs. ductile; Büttner et al. 2002; Liu et al. 2015b), whilst internal vesicle (and crystal) textures preserve information on the conditions of magma ascent (e.g. Klug and Cashman 1994; Cashman and Blundy 2000; Cashman, 2004; Lautze and Houghton 2007; Wright et al. 2012; Rust and Cashman 2011; Stovall et al. 2011; Stovall et al. 2012; Alfano et al. 2011; Murtagh and White 2013; Cioni et al. 2014). Differences in the size, shape and number density of bubbles that intersect particle surfaces can account for much of the morphological diversity within ash samples such that, for a given bubble population, particle shape and texture vary predictably between different grain-size classes (Genareau et al. 2012; Rausch et al. 2015; Liu et al. 2015a, b).

Our componentry data show that the ash componentsdense fragments, vesicular particles and shards - are the same in both the magmatic and hydromagmatic deposits, and have proportions that vary systematically as a function of grain size (Fig. 8). Density data (Fig. 9) further illustrate the increasing importance of internal vesicles at grain sizes $<0 \varphi(>1 \mathrm{~mm})$. At this grain size, the particle size exceeds the maximum bubble size and the relative length scales of bubbles and particles are sufficiently distinct that all particles can be classed as vesicular, and the individual particle morphology is independent of the bubble size distribution.

The size distributions of bubbles and particles progressively overlap and interact at particle sizes $>0 \varphi(<1 \mathrm{~mm})$. As the 
length scale of fragmentation approaches the modal bubble size, the size of bubbles increases relative to that of particles. This is reflected by an approximately linear increase in the proportions of both dense fragments and shards as the particle size decreases from $0 \varphi$ to $4 \varphi$. Dense fragments form by brittle fracture at a length scale smaller than the local size distribution of bubbles. They are most abundant in the $4 \varphi$ size fraction, which corresponds to the modal vesicle sizes in clasts of low to moderate vesicularity ( $<60 \%$; Fig. 10$)$. Shards represent the interstices between closely spaced bubbles and are most common in the $3 \varphi$ size fraction, which corresponds to the modal vesicle sizes in high vesicularity clasts (> 60\%; Fig. 10).

The componentry data can be combined with the grain size data to produce total component distributions (TCDs; Fig. 12). Here the distinction between magmatic and hydromagmatic deposits becomes clear. Magmatic deposits are dominated by particle sizes $>1 \mathrm{~mm}$ and, therefore, comprise, overwhelmingly, vesicular grains. In contrast, $90 \%$ of the total mass of the hydromagmatic deposit is $>0 \varphi$, with a broad mode in the TGSD between 1 and $4 \varphi(63-500 \mu \mathrm{m})$, and the component assemblage is dominated by dense fragments. Interestingly, however, although dense fragments dominate the hydromagmatic deposit by number (Fig. 12a), the TCD shows that by mass, they actually contribute a smaller proportion than vesicular particles (Fig. 12b).

To summarise, size-dependent variations in the proportions of different ash components are independently supported by corresponding measurements of mean particle density and vesicle texture, and are attributed to a bubble control on the scale and geometry of brittle fracture. That this is a general phenomenon is illustrated by comparing hydromagmatic ash from Hverfjall with ash deposits from the opening hydromagmatic phase of the 2011 Grímsvötn eruption (Fig. 13). There is a striking agreement between the relative proportions of dense to 'bubbly' (vesicular particles and shards) grains in hydromagmatic Hverfjall and Grímsvötn deposits over the shared range of grain sizes, which suggests that both the size and spatial distributions of bubbles in magma at the point of fragmentation were similar in the two eruptions.

\section{Vesiculation during the Hverfjall Fires}

A key observation from our study is that the vesicle textures, as measured by bubble number densities (BNDs), are similar for hydromagmatic and magmatic clasts from the Hverfjall Fires deposits (Fig. 1). As these pyroclasts have similar glass compositions (Liu 2016), BNDs can be considered a proxy for relative magma decompression rate (Cashman and Mangan 1994; Hurwitz and Navon 1994; Toramaru 2006; Mangan et al. 2014; Rust and Cashman 2011; Lautze and Houghton 2005; Murtagh and White 2013; Mangan et al. 2014). By this reasoning, the overlapping BNDs suggest similar magma ascent rates for both the magmatic and hydromagmatic vents. Using the empirical relation from Mangan et al. (2014), the observed BNDs correspond to mass eruption rates of $10^{5}$ to $10^{7} \mathrm{~kg} \mathrm{~s}^{-1}$ (hydromagmatic) and $10^{6}$ to $10^{7} \mathrm{~kg} \mathrm{~s}^{-1}$ (magmatic), both with an average of $\sim 1.2 \times 10^{7} \mathrm{~kg} \mathrm{~s}^{-1}$. The range of mass eruption rates for both magmatic and hydromagmatic vents overlap those typical of mafic lava fountain eruptions $\left(10^{5}\right.$ to $10^{6} \mathrm{~kg} \mathrm{~s}^{-1}$; Mangan et al. 2014), but extend an order of magnitude higher.

The vesicularities of Hverfjall Fires clasts are broadly similar to those measured in clasts from other mafic eruptions of low $\mathrm{H}_{2} \mathrm{O}$ and low crystallinity magmas (Fig. 1). Most important is the wide range in the vesicularity of hydromagmatic clasts relative to those of magmatic eruptions. The broad vesicularity distributions of hydromagmatic deposits are generally attributed to either the spatial heterogeneity of an

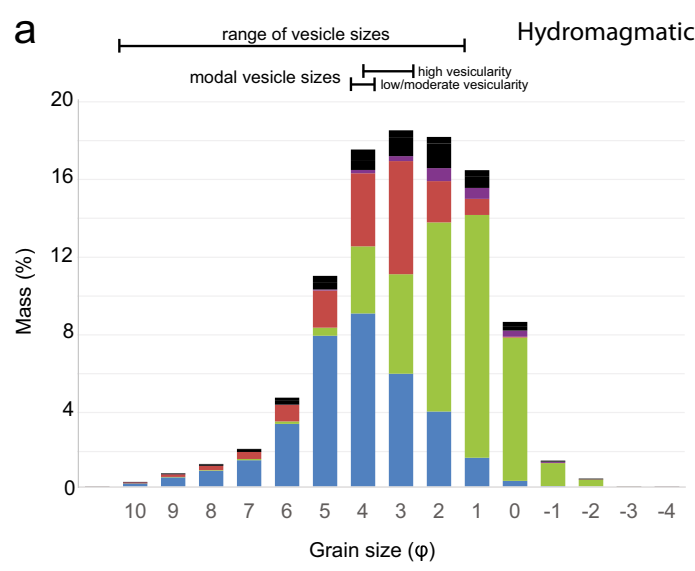

Fig. 12 a Total grain size distributions (TGSD) for the hydromagmatic fall and $\mathbf{c}$ GSD for a proximal magmatic scoria deposit [site Q1], showing the contributions of dense fragments (blue), vesicular particles (green), shards (red), microcrystalline grains (purple) and free crystals/lithics (black) to each size fraction (averaged over samples from a range of dispersal distances). Colour scheme is identical to Fig. 8. The range and
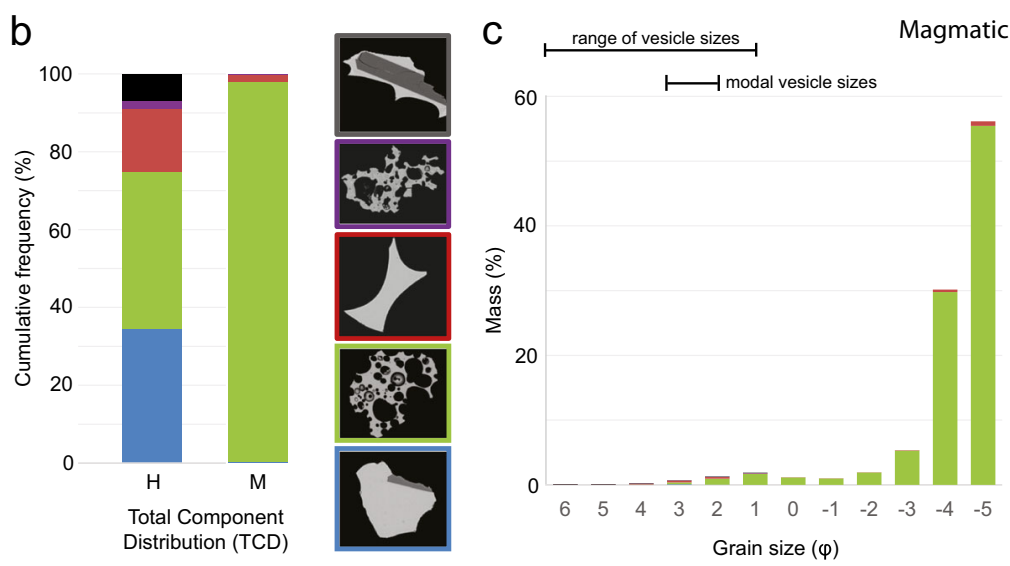

modal vesicle sizes from Fig. 9 are annotated for comparison. b Total componentry distributions (TCDs) for hydromagmatic fall (left) and magmatic scoria (right), determined by weighting the componentry of individual grain-size fractions by the total grain size distributions shown in $\mathbf{a}$ and $\mathbf{c}$ 
Fig. 13 Comparison of the relative proportions of dense fragments (black bars) and bubbly grains (shards and vesicular particles combined; pale grey bars) as a function of grain size, for the hydromagmatic deposits of the 2011 Grímsvötn (G; data from Liu et al. 2015b) and Hverfjall (HV; this study) eruptions. The data shown for each grain size represent averages of all samples of varying dispersal distances. The range of size fractions displayed is more restricted than shown in Fig. 8, to enable comparison with the size range analysed for the Grímsvötn deposits

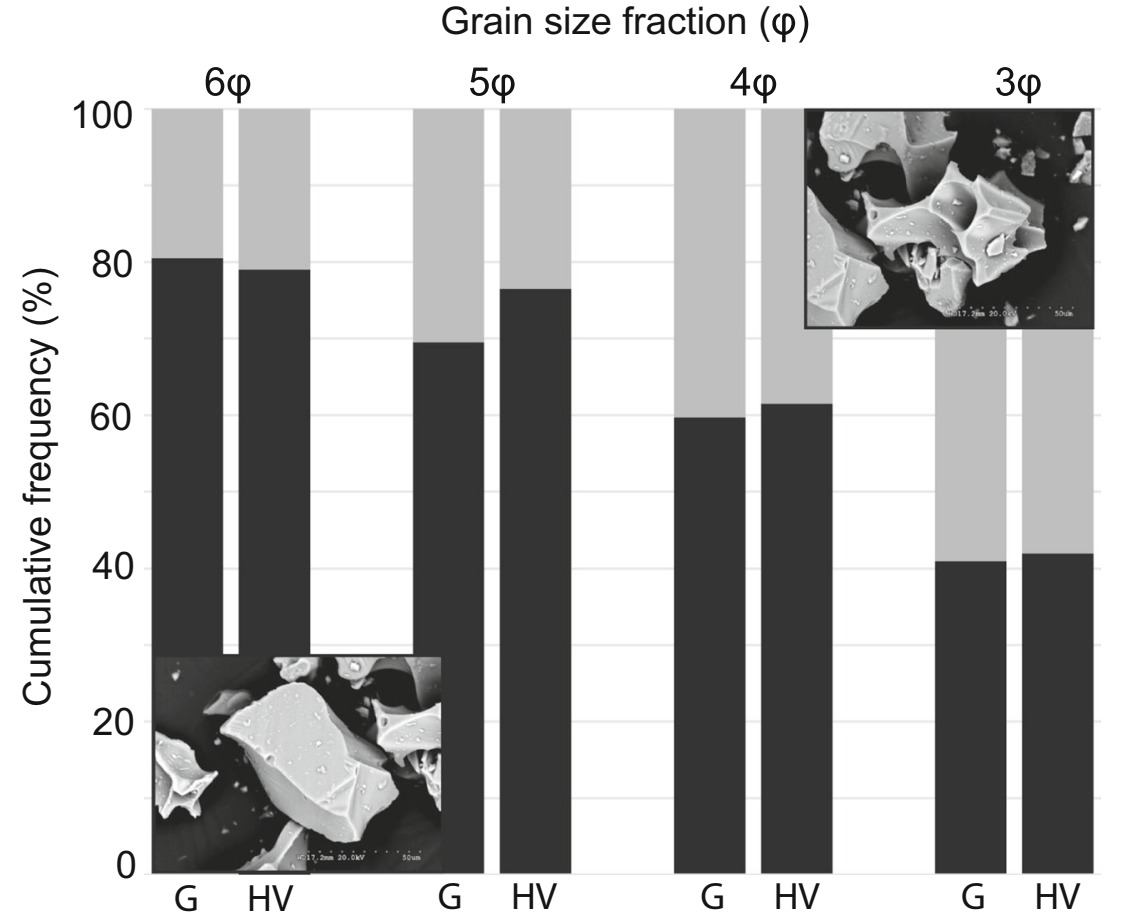

immature bubble population, or to fragmentation and quenching at different stages of vesiculation (e.g. Houghton and Wilson 1989; Murtagh and White 2013; Mastin et al. 2004). Figure 1 shows, however, that the vesicularities of both magmatic and hydromagmatic clasts from the Hverfjall Fires overlap between $\sim 50$ and $75 \%$, supporting the growing recognition that vesicularity is not a robust criterion to distinguish the eruptive products of magmatic from hydromagmatic fragmentation (Murtagh and White 2013; Grættinger et al. 2013; White and Valentine 2016).

Bubble number densities (BNDs) are also similar in the magmatic and hydromagmatic clasts from the Hverfjall Fires, although BNDs of hydromagmatic clasts are, on average, slightly higher. Figure 1 shows that BND data from the literature is more variable than the Hverfjall Fires in both magmatic and hydromagmatic samples. Much of the textural range in magmatic samples is interpreted to result from postfragmentation processes. Our data support this interpretation, as BNDs of hydromagmatic Hverfjall clasts and rims of magmatic clasts are similar to those of rapidly quenched rims of Kilauea Iki lapilli (Stovall et al. 2011; Porritt et al. 2012). Nevertheless, we acknowledge that magma heterogeneity within the conduit may also contribute to clast textural variability (e.g. Lautze and Houghton 2008).

Textural similarities between magmatic and hydromagmatic bubble populations indicate that differences in the vesiculation history cannot explain the contrasting fragmentation efficiencies. In the following section, we combine field observations with pyroclast measurements to discuss the controls on both fragmentation and eruptive style. In particular, we consider the contribution of differential cooling rates, and the resulting thermal stresses, to fine fragmentation of hydromagmatic pyroclasts.

\section{Eruptive processes during the Hverfjall Fires}

\section{Jarðbaðshólar scoria cones}

Magmatic activity at Jarðbaðshólar produced a coarse deposit dominated by scoriaceous lapilli and bombs, where pyroclast grain sizes are decoupled in scale from vesicle sizes by almost two orders of magnitude (Fig. 11). The grain size and morphological/textural properties of magmatic pyroclasts are comparable to those of other crystal-poor basaltic eruptions that involved no MWI (e.g. Kilauea, Hawaii; Parfitt 1998; Mangan and Cashman 1996) and are consistent with a fragmentation regime dominated by fluidal (inertial) break-up of low-viscosity magma. Under this regime, rapid bubble nucleation and expansion accelerates the melt phase, but does not directly contribute to the fragmentation process (Rust and Cashman 2011). Compared to erupted lava volumes, ash production was negligible and tephra deposition was largely confined to proximal vent regions (Einarsson 1991; Mattsson and Höskuldsson 2011).

\section{Hverfjall tuff ring}

Hydromagmatic activity at the Hverfjall vent produced finegrained unconsolidated ash fall, and poorly sorted indurated base surge, deposits rich in ash and accretionary lapilli. The 
transition from fall- to surge-dominated deposition has previously been attributed to a reduction in volumetric magma flux and, hence, a reduced ratio of magma to water in the vent, coincident with the onset of activity at Jarðbaðshólar (Mattsson and Höskuldsson 2011). Lowering of the magmawater ratio is widely associated with a decrease in the efficiency of MWI (e.g. Heiken and Wohletz 1985; Wohletz 1986). It is important to note, however, that the bulk volumetric proportions of magma and water in an environment of interaction do not necessarily translate to the proportions involved in direct interaction (White and Valentine 2016). Furthermore, the presence of surge deposits prior to the main phase of magmatic tephra fall from Jarðbaðshólar (Figs. 5 and S6) suggests that an additional mechanism is required to account for the change in interaction efficiency, such as a build-up of clastic material within the vent.

Our textural and componentry data demonstrate that the Hverfjall Fires magma was already vesiculating when it encountered groundwater and that the external water supply was sufficient to maintain MWI throughout the eruption, with no evidence for progressive exhaustion of a finite water reservoir. We propose that the spatial distribution of MWI (both laterally and stratigraphically) was determined by the pre-existing regional hydrology (Fig. 2b), where a propagating dike interacted with aquifers hosted within permeable basalt lavas. The large dimensions of the Hverfjall edifice relative to 'average' tuff rings, particularly the height of the crater rim (White and Ross 2011), may also reflect this prolonged activity. The high permeability, and thus the discharge rate of lava flow-hosted aquifers, are consistent with the continuous water supply required to maintain MWI, as observed for similarly 'over-sized' tuff rings/cones in coastal littoral settings such as in Hawaii and the Galapagos (Lorenz 1986, 2003).

Invoking a groundwater source raises the question of why hydromagmatic (or more specifically phreatomagmatic) activity was confined to the Hverfjall vent whilst Jarðbaðshólar remained 'dry', especially as the two coeval vents are $<5 \mathrm{~km}$ apart and within a few metres in elevation (Fig. 2). One possibility is that conductive heat flow from the laterally propagating dike feeding the Hverfjall vent locally dried up the groundwater in the area surrounding Jarðbaðshólar (Mattsson and Höskuldsson 2011). Our data can neither prove nor disprove this hypothesis. We note, however, the Hverfjall tuff ring is situated almost directly above the modern confluence of the two major groundwater flows (Kjaran and Hólm 1999; Einarsson et al. 2004) and, therefore, at local maxima in groundwater flow rate (Fig. 2b). Jarðbaðshólar, in contrast, appears to lie above a 'shadow' where the groundwater is deflected to the south, perhaps due to reduced permeability through the highly altered (palagonised) Námafjall hyaloclastite ridge directly to the east of Jarðbaðshólar
(DePaolo et al. 2001; Jarosch et al. 2008). In this scenario, the spatial distribution of phreatomagmatic activity is directly controlled by the pre-existing regional hydrological regime. A similar environmental control has been proposed to account for the distribution of phreatomagmatic vents within the Auckland volcanic field, New Zealand (Németh et al. 2012).

\section{The influence of cooling rate on hydromagmatic fragmentation}

The angular morphology of ash grains, together with the ubiquity of 'river-line' fracture patterns (Hull 1999) on exterior surfaces, indicates that brittle fragmentation dominates the formation of ash-sized pyroclasts. Brittle fragmentation requires that the timescale of deformation be shorter than the structural relaxation timescale (i.e. the melt crosses the glass transition; Dingwell and Webb 1989). At typical magmatic temperatures, brittle fragmentation of low-viscosity basaltic melts requires exceptionally high strain rates. The conditions for brittle fragmentation during MWI, in contrast, are easily established by rapid cooling of magma during interaction with external water (Mastin et al. 2004; Liu et al. 2015a; Van Otterloo et al. 2015). Interestingly, the presence of either complete or partial fluidal exterior surfaces on some particles (Fig. 7g, h) suggests prior (or contemporaneous) hydrodynamic break-up. Rapid magma ascent, as suggested by high BNDs, may have contributed to the development of hydrodynamic instabilities (Mangan and Cashman 1996).

Magma cooling rates during MWI are sufficient to generate the high thermal stresses required to exceed the thermal stress resistance (TSR) of silicate glass (Schmid et al. 2010; Schipper et al. 2011; Van Otterloo et al. 2015). Depending on the magnitude of thermal stress (a function of cooling rate and particle size, as well as material properties such as glass composition or bulk porosity), brittle failure can occur either during or after solidification (e.g. Chandrasekar and Chaudhri 1994; Patel et al. 2013). In this way, thermal stresses may trigger synchronous, or secondary, brittle fragmentation of pyroclasts formed hydrodynamically during volatile-driven acceleration (Schmid et al., 2010; Schipper et al. 2011; Liu et al. 2015b; Jutzeler et al. 2016). In contrast to the process of 'turbulent shedding' (Mastin et al. 2004; Mastin 2007), during which brittle fragmentation is limited to the shedding of glassy rinds formed on larger particles under turbulent cooling conditions, we propose that thermal stress can cause wholesale disintegration of pyroclasts.

If MWI occurs at sufficiently low pressure for volatile saturation, then the magma will contain gas bubbles, as was clearly the case for the Hverfjall Fires eruption. The presence of bubbles (voids) reduces the overall strength, thus rendering the magma more susceptible to breakage under any applied stress (e.g. Heap et al. 2014; Van Otterloo et al. 2015). In the context of quench granulation, this strength weakening 
reduces the maximum TSR, enabling fracturing at lower tensile thermal stresses (Zimanowski et al. 2003). Bubbles in glass can also influence the propagation and acceleration of brittle fractures by focusing fracture paths towards stress concentrations around bubbles (Green et al. 1977; Broek, 2012; Van Otterloo et al. 2015).

The efficiency of (pyroclast-producing) fragmentation was likely enhanced by the rapid thermal expansion of external water/steam during confined mixing, such as occurs during littoral explosions (Jurado-Chichay et al. 1996; Mattox and Mangan 1997) and which could also take place within an invent water-saturated slurry of fragmented lithic and pyroclastic material. Mixing/mingling between magma and an in-vent water-saturated sediment slurry was first proposed by Kokelaar (1986) and subsequently expanded in light of textural observations and thermodynamic considerations of ubiquitous entrained clasts in composite scoria lapilli and bombs from Surtseyan eruptions (White 1996; Schipper and White 2016). The abundance of lithic blocks and lapilli of dense basalt both in and around the Hverfjall tuff ring crater (Figs. $3 \mathrm{~g}$ and S4a, supplementary information) provides evidence of disruption of the basement substrate by subsurface explosions. Although the homogeneous lithology of basement rocks means that the lithic assemblage provides little indication of the absolute depth of disruption, the presence of lithic material throughout the depositional sequence requires either continuous country rock excavation (e.g. Lorenz 1986, 2003) or recycling and ejection of earlier disrupted material (Grættinger et al. 2014; Valentine et al. 2015). The development of an in-vent slurry would support the latter hypothesis (Kokelaar 1986; Schipper and White 2016), without the need to invoke continuous vent widening or vertical excavation to account for the erupted lithic assemblage. Together, the incorporation of recycled clasts within coarse ash and lapilli from the Hverfjall vent (Fig. 7c-e), the abundance of fine ash within outer and internal (in 2D) vesicles and the presence of thick ash-rich rinds on accretionary lapilli throughout the exposed crater section (Fig. S4) all lend further support to the slurry hypothesis.

The styles of magmatic (volatile-driven inertial break-up) and hydromagmatic (steam explosivity and/or thermal brittle disintegration) fragmentation inferred for Hverfjall are not mutually exclusive; moreover, plausible feedbacks exist whereby one process could trigger or amplify the other (e.g. Wohletz and Sheridan 1983; Wohletz 1986; Zimanowski et al. 1991; Zimanowski et al. 1997; Grættinger et al. 2014). For example, initial fluidal fragmentation could provide the inertia to drive fuel-coolant mixing with sufficient surface area to enable MFCI and associated fragmentation. Further brittle fragmentation due to thermal stress in the rapidly cooled glass may then occur during the subsequent expansion phase. Fragmentation during hydromagmatic eruptions likely occurs via a combination of all three processes, with spatial and/or temporal variation in the relative dominance of each mechanism.

\section{Conclusions}

The textures of hydromagmatic pyroclasts erupted during the Hverfjall Fires fissure eruption reveal that considerable vesiculation took place prior to magma-water interaction (MWI). Overlapping vesicularity and bubble number density distributions in rapidly quenched pyroclasts from both magmatic and hydromagmatic deposits echo the similarities seen in mafic pyroclasts more generally, and suggest comparable ascent (decompression) paths. Further, co-variation in particle size, shape and texture over the full range of available grain sizes suggests that hydromagmatic fragmentation occurred principally by brittle mechanisms, where the length scale and geometry of fracturing was controlled by the bubble population at the time of MWI. Interestingly, whilst ash with a 'blocky' morphology dominates the hydromagmatic deposit at grain sizes smaller than the modal bubble size, vesicular particles and bubble shards comprise the bulk of the deposit by mass when the total grain size distribution is considered. Together, these data support previous evidence from the 2011 Grímsvötn eruption, Iceland, that the shape and size distributions of hydromagmatic pyroclasts are strongly influenced by the dynamics of vesiculation prior to MWI and fragmentation (Liu et al. 2015a,b).

Interestingly, the preservation of partial fluidal outer surfaces on some ash-sized pyroclasts suggests not only that the magma was vesiculating when it encountered groundwater, but also that it may have been partially fragmented. As the pressure gradient between non-fragmented ascending magma and an adjacent aquifer under hydrostatic pressure would drive water away from the conduit, we suggest that magmatic fragmentation may be a pre-requisite for efficient magmawater interaction. Whether that interaction takes place at the conduit margins or by magma fountaining into a wet crater would depend on the depth of the groundwater table relative to the fragmentation surface, which may vary throughout an eruption (e.g. Mastin 1997).

We propose that the elevated fragmentation efficiency of hydromagmatic deposits is driven, at least in part, by residual thermal stresses in glass quenched during MWI (e.g. Dürig and Zimanowski 2012; Liu et al. 2015b). We explain fine fragmentation by magmatic vesiculation followed by rapid quenching and brittle breakage, which does not necessarily require pre-mixing of magma and water. Moreover, different mechanisms of magma fragmentation - explosivity by expansion of exsolved magmatic volatiles, steam explosivity and thermal granulation - are likely to operate simultaneously 
during hydromagmatic eruptions, with varying dominance in response to fluctuations in the magma supply or the availability of external water. In summary, we view magmatic volatiledriven and hydromagmatic fragmentation as end-members of a spectrum, rather than discrete eruptive states, and urge caution when interpreting MWI based on the properties of fine ash alone.

Acknowledgements The authors wish to thank T. Thordarson, J.D.L. White, and an anonymous reviewer for their careful and constructive reviews that greatly improved this manuscript. This work was completed with support for KVC from the AXA Research Fund and a Royal Society Wolfson Merit Award, a Royal Society URF to ACR and a University of Bristol postgraduate Scholarship to EJL. Fieldwork was supported by a New Researchers Award from the Geologists' Association to EJL. We thank S. Kearns and B. Buse for their assistance with SEM analysis.

Open Access This article is distributed under the terms of the Creative Commons Attribution 4.0 International License (http:// creativecommons.org/licenses/by/4.0/), which permits unrestricted use, distribution, and reproduction in any medium, provided you give appropriate credit to the original author(s) and the source, provide a link to the Creative Commons license, and indicate if changes were made.

\section{References}

Alfano F, Bonadonna C, Delmelle P, Costantini L (2011) Insights on tephra settling velocity from morphological observations. J Volcanol Geotherm Res 208(3-4):86-98

Aranda-Gómez J, Luhr JF (1996) Origin of the Joya Honda maar, San Luis Potosi, Mexico. J Volcanol Geotherm Res 74(1):1-18

Bonadonna C, Houghton B (2005) Total grain-size distribution and volume of tephra-fall deposits. Bull Volcanol 67(5):441-456

Bonadonna C, Biass S, Costa A (2015) Physical characterization of explosive volcanic eruptions based on tephra deposits: propagation of uncertainties and sensitivity analysis. J Volcanol Geotherm Res 296: $80-100$

Broek D (2012) Elementary engineering fracture mechanics. Springer science and business media

Brown RJ, Bonadonna C, Durant AJ (2012) A review of volcanic ash aggregation. Phys Chem Earth 45-46:65-78

Büttner R, Dellino P, Zimanowski B (1999) Identifying magma-water interaction from the surface features of ash particles. Nature 401(6754):688-690

Büttner R, Dellino P, La Volpe L, Lorenz V, Zimanowski B (2002) Thermohydraulic explosions in phreatomagmatic eruptions as evidenced by the comparison between pyroclasts and products from Molten Fuel Coolant Interaction experiments. J Geophys Res Solid Earth 107(B11):2277

Cashman K (2004) Volatile controls on magma ascent and eruption. In: Sparks RSJ, Hawkesworth CJ, (eds) State of the planet: Frontiers and challenges in geophysics, vol. 150. American Geophysical Monograph, 109-124

Cashman K, Blundy J (2000) Degassing and crystallization of ascending andesite and dacite. Philosophical Transactions of the Royal Society of London A: Mathematical. Phys Eng Sci 358(1770):1487-1513

Cashman KV, Mangan MT (1994) Physical aspects of magmatic degassing; II, constraints on vesiculation processes from textural studies of eruptive products. Rev Mineral Geochem 30(1):447-478

Chandrasekar S, Chaudhri M (1994) The explosive disintegration of Prince Rupert's drops. Philosophical Magazine B - Physics of
Condensed Matter Statistical Mechanics Electronic Optical and Magnetic Properties 70(6):1195-1218

Chough S, Sohn Y (1990) Depositional mechanics and sequences of base surges, Songaksan tuff ring, Cheju Island, Korea. Sedimentology 37(6):1115-1135

Cioni R, Sbrana A, Vecci R (1992) Morphologic features of juvenile pyroclasts from magmatic and phreatomagmatic deposits of Vesuvius. J Volcanol Geotherm Res 51(1):61-78

Cioni R, Pistolesi M, Bertagnini A, Bonadonna C, Hoskuldsson A, Scateni B (2014) Insights into the dynamics and evolution of the 2010 Eyjafjallajökull summit eruption (Iceland) provided by volcanic ash textures. Earth Planet Sci Lett 394:111-123

Cole P, Guest J, Duncan A, Pacheco JM (2001) Capelinhos 1957-1958, Faial, Azores: deposits formed by an emergent surtseyan eruption. Bull Volcanol 63(2-3):204-220

Colgate SA, Sigurgeirsson T (1973) Dynamic mixing of water and lava. Nature 244:552-555

Daggitt ML, Mather TA, Pyle DM, Page S (2014) AshCalc — a new tool for the comparison of the exponential, power-law and Weibull models of tephra deposition. J Appl Volcanol 3:7

Dellino P, Guðmundsson MT, Larsen G, Mele D, Stevenson JA, Thordarson T, Zimanowski B (2012) Ash from the Eyjafjallajokull eruption (Iceland): fragmentation processes and aerodynamic behavior. J Geophys Res Solid Earth 117:B00C04

DePaolo DJ, Stolper E, Thomas DM (2001) Deep drilling into a Hawaiian volcano. EOS Trans 82(13):149-154

Dingwell DB, Webb SL (1989) Structural relaxation in silicate melts and non-Newtonian melt rheology in geologic processes. Phys Chem Miner 16 (5)

Donald B, Dingwell, Sharon L, Webb, (1989) Structural relaxation in silicate melts and non-Newtonian melt rheology in geologic processes. Physics and Chemistry of Minerals 16 (5)

Dürig T, Zimanowski B (2012) "Breaking news" on the formation of volcanic ash: fracture dynamics in silicate glass. Earth Planet Sci Lett 335:1-8

Einarsson A (1982) The palaeolimnology of Lake Mývatn, northern Iceland: plant and animal microfossils in the sediment. Freshw Biol 12(1):63-82

Einarsson P (1991) Umbrotin við Kröflu 1975-1989. In: Garðarsson A, Einarsson Á (eds) Náttúra Mývatns. Hið íslenska náttúrufræðifélag, Reykjavík

Einarsson Á, Stefánsdóttir G, Jóhannesson H, Ólafsson JS, Gíslason GM, Wakana I, Gudbergsson G, Gardarsson A (2004) The ecology of Lake Mývatn and the River Laxá: variation in space and time. Aquat Ecol 38(2):317-348

Engwell S, Sparks R, Aspinall W (2013) Quantifying uncertainties in the measurement of tephra fall thickness. J Appl Volcanol 2(1):1-12

Eychenne J, Le Pennec J-L, Troncoso L, Gouhier M, Nedelec J-M (2012) Causes and consequences of bimodal grain-size distribution of tephra fall deposited during the August 2006 Tungurahua eruption (Ecuador). Bull Volcanol 74(1):187-205

Fierstein J, Nathenson M (1992) Another look at the calculation of fallout tephra volumes. Bull Volcanol 54(2):156-167

Fisher RV (1979) Models for pyroclastic surges and pyroclastic flows. J Volcanol Geotherm Res 6(3-4):305-318

Genareau K, Proussevitch AA, Durant AJ, Mulukutla G, Sahagian DL (2012) Sizing up the bubbles that produce very fine ash during explosive volcanic eruptions. Geophys Res Lett 39:L15306

Gjerløw E, Höskuldsson A, Pedersen R-B (2015) The 1732 Surtseyan eruption of Eggøya, Jan Mayen, North Atlantic: deposits, distribution, chemistry and chronology. Bull Volcanol 77(2):1-21

Graettinger AH, Skilling I, McGarvie D, Höskuldsson Á (2013) Subaqueous basaltic magmatic explosions trigger phreatomagmatism: a case study from Askja, Iceland. J Volcanol Geotherm Res 264:1735 
Grættinger A, Valentine G, Sonder I, Ross PS, White J, Taddeucci J (2014) Maar-diatreme geometry and deposits: subsurface blast experiments with variable explosion depth, Geochemistry, Geophysics. Geosystems 15(3):740-764

Green D, Nicholson PS, Embury J (1977) Crack shape studies in brittle porous materials. J Mater Sci 12(5):987-989

Heap MJ, Xu T, Chen CF (2014) The influence of porosity and vesicle size on the brittle strength of volcanic rocks and magma. Bull Volcanol 76(9):1-15

Heiken G, Wohletz K (1985) Volcanic ash. University Presses of California, Chicago, Harvard \& MIT

Hjartardóttir ÁR, Einarsson P, Bramham E, Wright TJ (2012) The Krafla fissure swarm, Iceland, and its formation by rifting events. Bull Volcanol 74(9):2139-2153

Houghton B, Hackett W (1984) Strombolian and phreatomagmatic deposits of Ohakune Craters, Ruapehu, New Zealand: a complex interaction between external water and rising basaltic magma. J Volcanol Geotherm Res 21(3):207-231

Houghton B, Nairn I (1991) The 1976-1982 Strombolian and phreatomagmatic eruptions of White Island, New Zealand: eruptive and depositional mechanisms at a 'wet' volcano. Bull Volcanol 54(1):25-49

Houghton B, Wilson C (1989) A vesicularity index for pyroclastic deposits. Bull Volcanol 51(6):451-462

Houghton B, Wilson C, Smith I (1999) Shallow-seated controls on styles of explosive basaltic volcanism: a case study from New Zealand. J Volcanol Geotherm Res 91(1):97-120

Hull D (1999) Fractography, Cambridge University Press

Jarosch A, Gudmundsson MT, Högnadóttir T, Axelsson G (2008) Progressive cooling of the hyaloclastite ridge at Gjálp, Iceland, 1996-2005. J Volcanol Geotherm Res 170(3):218-229

Jurado-Chichay Z, Rowland SK, Walker GPL (1996) The formation of circular littoral cones from tube-fed pāhoehoe: Mauna Loa, Hawai'i. Bull Volcanol 57(7):471-482

Jutzeler M, White JD, Proussevitch AA, Gordee SM (2016) Vesiculation and fragmentation history in a submarine scoria cone-forming eruption, an example from Nishiizu (Izu Peninsula, Japan). Bull Volcanol 78(2):1-25

Kawabata E, Cronin SJ, Bebbington MS, Moufti MRH, El-Masry N, Wang T (2015) Identifying multiple eruption phases from a compound tephra blanket: an example of the AD1256 Al-Madinah eruption, Saudi Arabia. Bull. Volcanol 77(1)

Mannen K (2006) Total grain size distribution of a mafic subplinian tephra, TB-2, from the 1986 Izu-Oshima eruption, Japan: An estimation based on a theoretical model of tephra dispersal. J Volcanol Geotherm Res 155 (1-2):1-17

Kjaran S and Hólm S (1999) Mývatn. Grunnvatnslíkan af vatnasvidi Mývatns, Technical report, Verkfrædistofan Vatnaskil

Klug C, Cashman K (1994) Vesiculation of May 18, 1980, Mount StHelens magma. Geology 22(5):468-472

Klug C, Cashman K, Bacon C (2002) Structure and physical characteristics of pumice from the climactic eruption of Mount Mazama (Crater Lake), Oregon. Bull Volcanol 64(7):486-501

Kokelaar P (1986) Magma-water interactions in subaqueous and emergent basaltic. Bull Volcanol 48(5):275-289

Kristmannsdóttir H, Ármannsson H (2004) Groundwater in the Lake Mývatn area, northern Iceland: chemistry, origin and interaction. Aquat Ecol 38(2):115-128

Kshirsagar P, Siebe C, Guilbaud MN, Salinas S (2016) Geological and environmental controls on the change of eruptive style (phreatomagmatic to Strombolian-effusive) of Late Pleistocene El Caracol tuff cone and its comparison with adjacent volcanoes around the Zacapu basin (Michoacán, México). J Volcanol Geotherm Res 318:114-133
Lautze NC, Houghton BF (2005) Physical mingling of magma and complex eruption dynamics in the shallow conduit at Stromboli volcano, Italy. Geology 33(5):425-428

Lautze NC, Houghton BF (2007) Linking variable explosion style and magma textures during 2002 at Stromboli volcano, Italy. Bull Volcanol 69(4):445-460

Lautze NC, Houghton BF (2008) Single explosions at Stromboli in 2002: Use of clast microtextures to map physical diversity across a fragmentation zone. J Volcanol Geotherm Res 170(3-4):262-268

Liu EJ (2016) The generation of volcanic ash during basaltic hydromagmatic eruptions: from fragmentation to resuspension. $\mathrm{PhD}$ Thesis, University of Bristol

Liu EJ, Cashman KV, Rust AC (2015a) Optimising shape analysis to quantify volcanic ash morphology. Geo Res J 8:14-30

Liu EJ, Cashman KV, Rust AC, Gislason S (2015b) The role of bubbles in generating fine ash during hydromagmatic eruptions. Geology 43(3):239-242

Lorenz V (1974) Vesiculated tuffs and associated features. Sedimentology 21(2):273-291

Lorenz V (1986) On the growth of maars and diatremes and its relevance to the formation of tuff rings. Bull Volcanol 48(5):265-274

Lorenz V (2003) Maar-diatreme volcanoes, their formation, and their setting in hard-rock or soft-rock environments. Andean Geol 15: $72-83$

Mangan M, Cashman K (1996) The structure of basaltic scoria and reticulite and inferences for vesiculation, foam formation, and fragmentation in lava fountains. J Volcanol Geothermal Res 73(1-2):1-18

Mangan MT, Cashman KV, Newman S (1993) Vesiculation of basaltic magma during eruption. Geol 21(2):157

Mangan MT, Cashman KV, Swanson DA (2014) The dynamics of Hawaiian-style eruptions: a century of study, in Poland, MP and Takahashi, TJ and Landowski, CM, (ed) Characteristics of Hawaiian volcanoes. US Geological Survey, pp. 323-354

Mannen K (2006) Total grain size distribution of a mafic subplinian tephra, TB-2, from the 1986 Izu-Oshima eruption, Japan: An estimation based on a theoretical model of tephra dispersal. J Volcanol Geotherm Res 155(1-2):1-17

Mangan MT, Cashman KV, Newman S (1993) Vesiculation of basaltic magma during eruption. Geology 21(2):157

Mastin LG (1997) Evidence for water influx from a caldera lake during the explosive hydromagmatic eruption of 1790 , Kilauea volcano, Hawaii. J Geophys Res: Solid Earth 102(B9):20093-20109

Mastin L (2001) A simple calculator of ballistic trajectories for blocks ejected during volcanic eruptions, US Geological Survey Open File Report 2001-45

Mastin LG (2007) Generation of fine hydromagmatic ash by growth and disintegration of glassy rinds. J Geophys Res: Solid Earth 112 : B02203

Mastin LG, Christiansen RL, Thornber C, Lowenstern J, Beeson M (2004) What makes hydromagmatic eruptions violent? Some insights from the Keanakako'i Ash, Kilauea Volcano, Hawai'i. J Volcanol Geotherm Res 137(1):15-31

Mattox TN, Mangan MT (1997) Littoral hydrovolcanic explosions: a case study of lava-seawater interaction at Kilauea Volcano. J Volcanol Geotherm Res 75(1):1-17

Mattsson HB (2010) Textural variation in juvenile pyroclasts from an emergent, Surtseyan-type, volcanic eruption: The Capelas tuff cone, SÃ£o Miguel (Azores). J Volcanol Geotherm Res 189(1-2):81-91

Mattsson HB, Höskuldsson Á (2011) Contemporaneous phreatomagmatic and effusive activity along the Hverfjall eruptive fissure, north Iceland: Eruption chronology and resulting deposits. J Volcanol Geotherm Res 201(1):241-252

Moore J (1967) Base surge in recent volcanic eruptions. Bull Volcanol 30(1):337-363 
Murrow PJ, Rose WI, Self S (1980) Determination of the total grain size distribution in a vulcanian eruption column, and its implications to stratospheric aerosol perturbation. Geophys Res Lett 7(11):893-896

Murtagh RM, White JD (2013) Pyroclast characteristics of a subaqueous to emergent Surtseyan eruption, Black Point volcano, California. J Volcanol Geothermal Res 267:75-91

Murtagh RM, White JD, Sohn YK (2011) Pyroclast textures of the Ilchulbong 'wet' tuff cone, Jeju Island, South Korea. J Volcanol Geotherm Res 201(1):385-396

Németh K, Cronin SJ (2011) Drivers of explosivity and elevated hazard in basaltic fissure eruptions: the 1913 eruption of Ambrym Volcano, Vanuatu (SW-Pacific). J Volcanol Geotherm Res 201(1):194-209

Németh K, Cronin SJ, Charley D, Harrison M, Garae E (2006) Exploding lakes in Vanuatu-" Surtseyan-style" eruptions witnessed on Ambae Island. Episodes 29(2):87

Németh K, Cronin SJ, Smith IE, Flores JA (2012) Amplified hazard of small-volume monogenetic eruptions due to environmental controls, Orakei Basin, Auckland Volcanic Field, New Zealand. Bull Volcanol 74(9):2121-2137

Parcheta C, Houghton B, Swanson D (2013) Contrasting patterns of vesiculation in low, intermediate, and high Hawaiian fountains: a case study of the 1969 Mauna Ulu eruption. J Volcanol Geotherm Res 255:79-89

Parfitt EA (1998) A study of clast size distribution, ash deposition and fragmentation in a Hawaiian-style volcanic eruption. J Volcanol Geotherm Res 84(3):197-208

Patel A, Manga M, Carey RJ, Degruyter W (2013) Effects of thermal quenching on mechanical properties of pyroclasts. J Volcanol Geotherm Res 258:24-30

Peckover R, Buchanan D, Ashby D (1973) Fuel-coolant interactions in submarine vulcanism. Nature 245:307-308

Pedrazzi D, Martí J, Geyer A (2013) Stratigraphy, sedimentology and eruptive mechanisms in the tuff cone of El Golfo (Lanzarote, Canary Islands). Bull Volcanol 75(7):1-17

Polacci M, Burton MR, La Spina A, Murè F, Favretto S, Zanini F (2009) The role of syn-eruptive vesiculation on explosive basaltic activity at Mt. Etna, Italy. J Volcanol Geotherm Res 179(3-4):265-269

Porritt LA, Russell JK, Quane SL (2012) Pele's tears and spheres: examples from Kilauea Iki. Earth Planet Sci Lett 333:171-180

Pyle DM (1989) The thickness, volume and grainsize of tephra fall deposits. Bull Volcanol 51(1):1-15

Rausch J, Grobéty B, Vonlanthen P (2015) Eifel maars: quantitative shape characterization of juvenile ash particles (Eifel Volcanic Field, Germany). J Volcanol Geotherm Res 291:86-100

Rose WI, Bonis S, Stoiber RE, Keller M, Bickford T (1973) Studies of volcanic ash from two recent Central American eruptions. Bull Volcanol 37(3):338-364

Ross PS, White JD (2012) Quantification of vesicle characteristics in some diatreme-filling deposits, and the explosivity levels of magma-water interactions within diatremes. J Volcanol Geotherm Res 245:55-67

Rust A, Cashman K (2011) Permeability controls on expansion and size distributions of pyroclasts. J Geophys Res: Solid Earth 116:B11202

Sæmundsson K (1991) Jardfrædi Kröflukerfisins. In: Garðarsson A, Einarsson Á (eds) 'Náttúra Mývatns', 662. Hid íslenska Náttúrufrædifélag, Reykjavík, pp 24-95

Sahagian DL, Proussevitch AA (1998) 3D particle size distributions from 2D observations: stereology for natural applications. J Volcanol Geotherm Res 84(3):173-196

Schipper CI, White JD (2016) Magma-slurry interaction in Surtseyan eruptions. Geology G37480-1

Schipper CI, White JDL, Zimanowski B, Büttner R, Sonder I, Schmid A (2011) Experimental interaction of magma and "dirty" coolants. Earth Planet Sci Lett 303(3-4):323-336

Schmid A, Sonder I, Seegelken R, Zimanowski B, Büttner R, Gudmundsson MT, Oddsson B (2010) Experiments on the heat discharge at the dynamic magma-water-interface. Geophys Res Lett 37(20):L20311

Self S, Sparks R, Booth B, Walker G (1974) The 1973 Heimaey strombolian scoria deposit, Iceland. Geol Mag 111(06):539-548

Sheridan MF, Wohletz KH (1983) Hydrovolcanism: basic considerations and review. J Volcanol Geotherm Res 17(1):1-29

Sohn YK (1996) Hydrovolcanic processes forming basaltic tuff rings and cones on Cheju Island, Korea. Geol Soc Am Bull 108(10):1199 1211

Solgevik H, Mattsson HB, Hermelin O (2007) Growth of an emergent tuff cone: fragmentation and depositional processes recorded in the Capelas tuff cone, São Miguel, Azores. J Volcanol Geotherm Res 159(1):246-266

Sparks RSJ, Wilson L, Sigurdsson H (1981) The pyroclastic deposits of the 1875 eruption of Askja, Iceland. Philos Trans R Soc A Math Phys Eng Sci 299(1447):241-273

Stovall WK, Houghton B, Gonnermann H, Fagents S, Swanson D (2011) Eruption dynamics of Hawaiian-style fountains: the case study of episode 1 of the Kilauea Iki 1959 eruption. Bull Volcanol 73(5): 511-529

Stovall WK, Houghton BF, Hammer JE, Fagents SA, Swanson DA (2012) Vesiculation of high fountaining Hawaiian eruptions: episodes 15 and 16 of 1959 Kilauea Iki. Bull Volcanol 74(2):441-455

Toramaru A (2006) BND (bubble number density) decompression rate meter for explosive volcanic eruptions. J Volcanol Geotherm Res 154(3-4):303-316

Pórarinsson S (1952) Hverfjall I, Náttúrufrædingurinn 22:113-129

pórarinsson S (1967) Surtsey: the new island in the North Atlantic, Viking Press

Pórarinsson S (1979) The postglacial history of the Mývatn area, Oikos $17-28$

Thordarson T, Höskuldsson Á (2008) Postglacial volcanism in Iceland. Jökull 58:197-228

Valentine GA, Krier D, Perry FV, Heiken G (2005) Scoria cone construction mechanisms, Lathrop Wells volcano, southern Nevada, USA. Geology 33(8):629-632

Valentine GA, Krier DJ, Perry FV, Heiken G (2007) Eruptive and geomorphic processes at the Lathrop Wells scoria cone volcano. J Volcanol Geotherm Res 161(1):57-80

Valentine GA, Sottili G, Palladino DM, Taddeucci J (2015) Tephra ring interpretation in light of evolving maar-diatreme concepts: Stracciacappa maar (central Italy). J Volcanol Geotherm Res 308: 19-29

Van Otterloo J, Cas RA, Sheard MJ (2013) Eruption processes and deposit characteristics at the monogenetic Mt. Gambier Volcanic Complex, SE Australia: implications for alternating magmatic and phreatomagmatic activity. Bull Volcanol 75(8):1-21

Van Otterloo J, Cas RA, Scutter CR (2015) The fracture behaviour of volcanic glass and relevance to quench fragmentation during formation of hyaloclastite and phreatomagmatism. Earth-Sci Rev 151:79116

Vaughan RG, Webley PW (2010) Satellite observations of a surtseyan eruption: Hunga Ha'apai, Tonga. J Volcanol Geotherm Res 198(1): $177-186$

Walker G (1971) Grain-size characteristics of pyroclastic deposits. J Geol 79(6):696-714

Walker G (1973) Explosive volcanic eruptions: a new classification scheme. Geol Rundsch 62(2):431-446

Walker G, Croasdale R (1971) Characteristics of some basaltic pyroclastics. Bull Volcanol 35(2):303-317

Waters AC, Fisher RV (1971) Base surges and their deposits: Capelinhos and Taal volcanoes. J Geophys Res 76(23):5596-5614

White JD (1996) Impure coolants and interaction dynamics of phreatomagmatic eruptions. J Volcanol Geotherm Res 74(3):155170 
White JD, Ross P-S (2011) Maar-diatreme volcanoes: a review. J Volcanol Geotherm Res 201(1):1-29

White J, Valentine G (2016) Magmatic versus phreatomagmatic fragmentation: absence of evidence is not evidence of absence, in $2015 \mathrm{AGU}$ Fall Meeting Abstracts. AGU V33B-3108

Wohletz K (1983) Mechanisms of hydrovolcanic pyroclast formation: grainsize, SEM, and experimental studies. J Volcanol Geotherm Res 17(1-4):31-63

Wohletz KH (1986) Explosive magma-water interactions: thermodynamics, explosion mechanisms, and field studies. Bull Volcanol 48(5): 245-264

Wohletz K, Sheridan M (1983) Hydrovolcanic explosions 2. Evolution of basaltic tuff rings and tuff cones. Am J of Sci 283(5):385-413
Wright HM, Cashman KV, Mothes PA, Hall ML, Ruiz AG, Le Pennec JL (2012) Estimating rates of decompression from textures of erupted ash particles produced by 1999-2006 eruptions of Tungurahua volcano, Ecuador. Geology 40(7):619-622

Zimanowski B, Fröhlich G, Lorenz V (1991) Quantitative experiments on phreatomagmatic explosions. J Volcanol Geotherm Res 48(3):341358

Zimanowski B, Büttner R, Lorenz V, Häfele H-G (1997) Fragmentation of basaltic melt in the course of explosive volcanism. J Geophys Res: Solid Earth 102(B1):803-814

Zimanowski B, Wohletz K, Dellino P, Büttner R (2003) The volcanic ash problem. J Volcanol Geotherm Res 122(1-2):1-5 